\title{
O crime politico e a fórma de seu julgamento na ditadura fascista brasileira
}

\section{Waldemar Ferreira}

Mais voluvel conceito se não depara do que o do crime politico. Varía no tempo e no espaço. E o processo de apurá-lo e julgá-lo é, mais ou menos, o mesmo, em tal ou qual regime politico, assim nos rescaldos revolucionários, como na transitoriedade, curta ou alongada, dos regimes ditatoriais.

Assim f'oi, como não podia deixar de ser, na ditadura fascista instaurada no Brasil em 1937, por movimento branco das forças armadas, e por elas mesmas encerrada, sem gôta de sangue, em 1945. Num e noutro caso, no meio da indiferença nacional, surpreendida pelos acontecimentos.

Para que tal regime se implantasse, o trabalho revolucionário, orientado e dirigido pelo chefe do govêrno, fez-se em silêncio, à revelia da opinião pública nacional, embóra, na Câmara dos Deputados, fôsse êle denunciado. Por isso, teve ela sua voz abafada pelo golpe de Estado, que a dissolveu, e pela mais desabusada das censuras, que depois se lhe seguiu. Para que tal regime caisse, movimentou-se a opinião pública, graças à suspensão da censura, tempos depois, e somente nos primeiros mêses de 1945 , imposta pela pressão da opinião int'ernacional. Ainda assim, o golpe, que depôs o ditador, foi tão rapidamente desferido, que a Nação nem teve tempo de acompanhar-lhe os lânces.

Nêsse golpe, as forças armadas se redimiram, pois que não alçaram uma ditadura em lugar de outra, mas entregaram o poder ao judiciário, investindo o presidente do Supremo Tribunal Federal na suprema magistratura da Nação. 
Para que, porém, se possa aquilatar de como agiu a ditadura fasc.sta deposta contra os que persistiram em manter as suas convicções democráticas, passa-se a trauscrever, nestas páginas, a petıção de habeas-corpus, impetrado pelos advogados brasileiros em favor de exilados politicos brasileiros e que o Supremo Tribunal Federal, unanimemente concedeu, por acórdão de 11 de abril de $1945\left({ }^{\star}\right)$. Redigiu-a WALdemar Ferreira. Subscreveram-na mais de mil advogados de São Paulo, do Rio de Janeiro, de Minas Gerais e da Baia, muitos por telegrâmas endereçados à mais alta Côrte de Justica do Brasil.

Comentando o grande julgado, que tão profundamente repercutiu em todo o país, em sua edição do dia seguinte, o

( ') 0 acórdão, qual se publicou no Diário da Justiça apenso ao n. 249, de 1 de novembro de 1945. do Diário Oficial, do Rio de Janeiro, é do seguinte teôr:

\section{ACORDÃO}

Vistos, relatados e discutidos êstes autos de Habeas-corpus n. 29.002, do Distrito Federal, em que são pacientes os Drs. ARMANDO DE SALES OLIVEIRA, OTÁVIO MANGABEIRA e PAULO NOGUEIRA FILHO, resolvem os Ministros do Supremo Tribunal Federal conceder a ordem, por unanimidade de votos, de acôrdo com as notas taquigráficas anexas.

Rio, 11 de abril de 1945. - EDUARDO ESPINOLA, Presidente. - ANIBAL FREIRE, Relator.

\section{RELATÓRIO}

O Sr. Ministro Anibal Freire - Em longa petição, o professor Dr. WALDEMAR FERREIRA e outros advogados, em número avultado, impetram a êste Tribunal uma ordem de habeas-corpus, em favor dos Drs. ARMANDO DE SALES OLIVEIRA, OTÃVIO MANGABEIRA e PAULO NOGUEIRA FILHO, condenados pelo Tribunal de Segurança Nacional a 2 anos de prisão, grau minimo do art. $3 .^{\circ}$ inciso 9..$^{\circ}$ do Decreto-Iei n..$^{\circ} 431$, de 1938.

Começa a petição por descrever o movimento conspiratório que declara ter sido policialmente arquitetado em São Paulo para chegar ao resultado almejado, o fechamento do Estado de São Paulo.

Salienta que do processo foram exclúídos quarenta e três dos inidiciados, de molde a prosseguir contra dez, sete dos quais foram absolvidos, vindo finalmente a ser condenados apenas os Drs. ARMANDO DE SALES OLIVEIRA, OTÁVIO MANGABEIRA e PAUlo NOGUEIRA FILHO.

Aponta em seguida a petição a nulidade do processo e sentença condenatória. Neste ponto começa por acentuar a qualidade de exilados dos condenados, o que é notório, além de estar comprovado pela própria denuncia do Sr. Dr. Procurador adjunto ao Tribunal de Segurança Nacional.

Estando assim êles expatriados. com residências conhecidas em Nova York e Buenos Aires, teriam sido êles fảcilmente citados e assim o entendeu judiciosamente o juiz da 1." instância, Dr. PEREIRA BRAGA. Divergiu, 
Jornal do Comercio, do Rio de Janeiro, nêstes termos se exprimiu :

"Não nos cabe aqui examinar os fundamentos da sentença, nem discutir os termos do processo, em virtude do qual foi proferida a condenação. São aspectos juridicos de natureza doutrinária, em torno de uma questão politica ligada estreitamente ao regime instituido em 10 de novembro de 1937 e cuja análise escapa, no momento, ao objetivo dêste comentário.

"Queremos apenas acentuar que a decisão da suprema Côrte de Justiça do país constitúe, nesta hora de graves preocupaçôes, uma garantia de que a magistratura brasileira sobrevive, serena e integra, na magnitude de sua m:ssão, apezar da desorientação e do confusionismo que amea-

porém, do entendimento o Tribunal pleno, que mandou aplicar ao caso o parágrafo único do art. $4 .^{\circ}$ do Decreto-lei n.॰ 474, de 8 de junho de 1938.

Tornou-se, assim, o processo radicalmente nulo, por falta de citação pessoal dos acusados, pois não se achavam os mesmos soltos nem foragidos.

Invoca a petição em abono do seu ponto de vista o julgamento proferido pelo Supremo Tribunal Federal nos autos de habeas-corpus numero 28.872, de Sergipe, de que foi relator o Sr. Ministro LAUDO DE CAMARGO (acórdão de 3 de dezembro de 1944).

Passa a petição a considerar a injustiça e inexiqüibilidade da sentença condenatória. Estende-se a êsse respeito, èm amplas considerações, acentuando não haver crime na crítica, embora em têrmos vivazes, do panorama político brasileiro.

Acrescenta em seguida a peitção que mudou sensivelmente a ordem politica, abrindo-se por fôrça das circunstâncias, tanto internas quanto e principalmente extrenas, ou melhor, internacionais, o debate em tôrno do sistema político e administrativo, suspendendo-se a censura à imprensa, permitindo-se a manifestação livre da opinião de doutos, academias, institutos.

"Como, em tais condições, pensar na execução da sentença condenatória pelo mesmo crime, se crime se praticou, dos três exilados brasileiros, quando agora e evidentemente crime tal não se considera?"

Em eruditas considerações, a petição desenvolve o seu ponto de vista, relembrando a opinião de autores sôbre a mitigação da relação jurídica e abrrogação das leis meramente outorgadas em regimes ditatoriais.

\section{Conclui a petição:}

"Cabe habeas-corpus sempre que alguém sofra ou se ache na iminência de sofrer violência ou coação ilegal na sua liberdade de ir e vir, salvo nos casos de punição disciplinar. Considera, de resto, o art. 648, ns. VI e VII, do Código de Processo Penal, coação ilegal a manifesta nulidade de processo, bem assim a instauração dêste, extinta a punibilidade. Do mesmo modo, é 
çam subverter a ordem dos valores morais e sociais da vida brasileira.

" $O$ voto unânime dos juizes que compõem o egrégio Supremo Tribunal Federal traz à Nação inquieta a segurança de que a justiça no Brasil paira acima dos interêsses politicos, não se intimida com as restrições à sua soberania, não recúa diante das armas do arbítrio punitivo do poder. Invocada pelos oprimidos, ressurge independente, para restaurar o direito ofendido e proteger a liberdade cerceada.

"Neste momento de tanta dúvida e inquietação, a decisão de ôntem do Supremo Tribunal Federal reafirma no Brasil a grandeza do Poder Judiciário, cúpola magnificente da vida democrática de um povo, força que o protege, defende e ampara contra a violência, a ilegalidade e a injustiça.

de concluir, o julgamento dêle, ou, ainda, a execução da sentença nele proferida. Que é manifestamente nulo o procseso em que se lançou a sentença condenatória dos Drs. ARMANDo DE SALES OLIVEIRA, OTÃVIO MANGABEIRA e PAULO NOGUEIRA FILHO, à saciedade se demonstrou, sobretudo em face do acórdão de 3 de dezembro de 1944 , consignado nos autos do habeas-corpus $n .^{\circ}$ 28.872, do Estado de Sergipe. Que a sentença é injusta e inexequivel, diante da mudança das condições que alteraram a ordem jurídica, que poderia justificá-la, se nula não fôsse, é de incomparável evidência. Eis a coação ilegal. Violência inaudita, por último, constitúi o exilio forçado dos três brasileiros sôbre os quais a ditadura desfechou o raio da sua perseguição.

Concedendo-lhes a ordem de habeas-corpus, que em favor dêles se impetra, para que cessem a violência e coação ilegais, de que são vítimas, de molde a poderem, livres de culpa e pena, retornar a sua Pátria, o Égrégio Supremo Tribunal Federal, substituindo o arbitrio pela lei, cumprirá, mais uma vez, sua alta missão, de incorruptível nobreza, como poder moderador das rudesas governamentais e assegurador dos direitos do homem.

Nestes têrmos, D. e A., com os documentos anexos".

0 pedido veio acompanhado de vários documentos. Solicitei informações ao Exmo. Sr. Presidente do Tribunal de Segurança Nacional, que, imediatamente, me enviou o seguinte ofício acompanhado de todo o processo.

"Em atenção ao Ofício $\mathrm{n} .^{\circ} 49$, de 5 do corrente, solicitando informações a respeito do que alegam os advogados dos pacientes na petição inicial de habeas-corpus $n .^{\circ} 29.002$, impetrado a êsse Egrégio Tribunal em favor de Armando de Sales Oliveira, Otávio Mangabeira e Paulo Nogueira Filho, esclareço a V. Exa. que ditos acusados denunciados como incursos, o primeiro nos incisos 9 e 13 do art. $3 .^{\circ}$ do Decreto-lei número 431 de 1933 
"A expressiva demonstração ontem verificada de que essa força perdura em meio dos erros, incertezas e desvairos desta hora, é reconfortante esperança que surge para os que anseiam por ver o pais retomar em ordem o rítmo de sua evolução democrática, no respeito às tradições juridicas de sua formação histórica."

A petição de habeas-corpus, suprimidos seu introito e seu final, fórmulas judiciárias comuns, é a que se segue.

\section{CAPITULO I}

O movimento conspiratório, policialmente arquitetado, para

- fechamento de grande órgão do jornalismo brasileiro.

1. Nos últimos dias do mês de março de 1940, realizou a polícia do Estado de São Paulo a prisão de cerca de cinquenta pessoas,

C-c art. 5., número II letra "b", da Consolidação das Leis Penais, no processo número 1.142, desta Capital, foram absolvidos por sentença de 4 de dezembro de 1940 , reformada na Apelação n. ${ }^{\circ} 663$, por Acórdão de 17-12-1940, para condenar os referidos acusados a 2 anos de prisão, grau mínimo do art. $3 .^{\circ}$, inciso 9 . do Decreto-lei n..$^{\circ} 431$, citado.

Outrossim, para melhor elucidação da hipótese, esta Presidência encaminha a $\mathrm{V}$. Exa. os autos do processo n..$^{\circ} \mathbf{1 . 1 4 2}$ (apelação 663), em que foram condenados os pacientes, para que êsse Egrégio Tribunal aprecie devidamente as alegações feitas na petição inicial.

Reitero a V. Exa. os meus protestos de elevada estima e distinta consideração.

o Presidente do Tribunal de Segurança Nacional. - F. de Barros Barreto, Ministro."

Em 4 dêste mês o advogado doutor Rubens Sousa Barreto, de São Paulo, pediu fazer juntar aos autos, razões sôbre o pedido formulado, renovando argumentos jả expendidos e invocando jurisprudência do Supremo Tribunal Federal sôbre desigualdade na aplicação de lei por parte do poder público.

Fiz igualmente juntar aos autos telegramas de vários advogados da Bahia e desta Capital, de ampla solidariedade com os impetrantes.

\section{VOTO}

o Sr. Ministro Anibal Freire - Dois são os fundamentos do pedido: injustiça e inexeqüibilidade da sentença condenatória e nulidade do processo e sentença por vicio de citação.

De referência à injustiça da sentença o âmbito do habeas-corpus não permite o conbecimento da matéria, além de que a lei básica não nos outorga a faculdade de órgão de cassação dos arestos de outros tribunais. A simples alegação do desıcêrto não pode cimentar as nossas decisões. Só 
quase todas filiadas ao então extinto Partido Constitucionalista, por suspeitas de acharem-se envolvidas em trama subversiva, que teria sido chefiada pelo primeiro signatanio desta, com o fim do desencadeamento de golpe armado contra os poderes constituídos. Manifestara-se ela, ao sentir das autoridades que conheceram do caso, por intensa propaganda política, desenvolvida em ocasiões propícias, discursos candentes, entrevistas nos jornais, reuniões no edifício da emprêsa jornalística $O$ Estado de São Paulo e nas residencias de alguns proceres políticos, coincidindo com franca distribuição de manifestos subversivos de autoria ou de responsabilidade dos drs. Armando de Salles Oliveira, Octavio Mangabeira, e Paulo NogueiRA Frluo procedentes dos países onde estes se acham, ou, como disse o Procurador-adjunto, em sua denúncia ao Tribunal de Segurança Nacional, "onde se encontram exilados como elementos nocivos aos interêsses nacionais". Saliente-se, desde logo, êste fato, sobremodo significativo e afirmado pela autoridade pública, de en-

quando se verifica atentado contra a lei, tem de operar-se a ação reparadora do direito por parte dêste tribunal.

Ao discutir-se neste pretório a competência dêle para o conhecimento das decisões em habeas-corpus do Tribunal de Segurança Nacional, COSTA MANSO, com a sua grande autoridade exprimiu em síntese conceito tradicionalmente seguido:

"O Supremo Tribunal Federal não pode, em julgamento de habeas-corpus, emendar as decisões dos tribunais inferiores. Desde, porém, que o constrangimento seja ilegal, isto é, extrinsecamente contrário à lei, o remédio constitucional é admissivel".

CASTRO NUNES, no seu magnifico trabalho sôbre o Poder Judiciário asserta:

"O Supremo Tribunal não se substitúi ao Tribunal de Segurança para rever ou reformar, comło instância superior a sua decisão. Limita-se a examinar, pelo habeas-corpus ou por via de conflito, a conformidade do exercício da jurisdição com a preceituação legal ou constitucional."

Como se vê, sempre a observância do conteúdo legal em face da decisão; jamais o exame das razões de conciência que impulsionaram a ação do julgador.

Cumpre agora considerar o aspecto da inexeqüibilidade da sentença.

A despeito da valia e realce dos ilustres signatários da petição, não se me afigura que lhes assista razão neste ponto.

Não se trata na hipótese de apreciar os efeitos de um ato de autoridade referente à liberdade do indivíduo, nem sequer se esboça neste feito a duplicidade de conduta do poder administrativo na aplicação das leis concernentes à livre manifestação do pensamento por todos os meios postos ao alcance dos membros da comunhão social, hipótese em que ao judiciário poderia caber o exercício de uma ação niveladora.

Em substância o que se pleiteia é a inexeqüibilidade de uma sentença condenatória, proferida por tribunal competente, sòmente porque o objeto da condenação passou na fase atual da vida do país a ser encarado por outro prisma pelos agentes da administração pública. 
contrarem-se os pacientes exilados e, pois, no cumprimento de pena, que já lhes havia sido imposta pelo govêrno da República.

Ao mesmo tempo em que as prisões se efetuaram, em 25 de março de 1940 , o govêrno fedéral, por portaria e intermédio do exmo. sr general ministro da Guerra, e tal está dito na denúncia acima referida, ordenou à Superintendência de Segurança Política e Social de São Paulo o fechamento da redação do jornal $O$ Estado de São Paulo, cujas atividades redatoriais cessaram naquela data, reabrindo-se depois, mas na posse, administração e redação de prepostos do Departamento de Imprensa e Publicidade, ou seja o Dip.

2. Remonidos os presos políticos para o Rio de Janeiro e recolhidos, a princípio, a quartéis e fortaleza do Exército, e depois ao quartel do Regimento de Cavalaria da Polícia Militar do Distrito Federal, prosseguiu o inquérito a propósito aberto; e, aos 26 de abril de 1940, pelo dr. Joaquim da Silva Azevedo, procurador-adjunto, com fundamento nêle e em obediência ao art. 39 do decreto-lei n. 474, de 8 de junho de 1938, combinado com a alínea b) do art. 41 do negimento interno do Tribunal de Segurança, a êste, inicialmente,

As pessoas mencionadas no pedido foram condenadas no grau minimo do art. 3. ${ }^{\circ}$ inciso 9 do Decreto-lei número 431, que define os crimes contra a personalidade internacional, a estrutura e a segurança do Estado e contra a ordem social. Esse inciso refere-se à propaganda ou à posse de boletins, panfletos ou quaisquer outras publicações.

A lei enumera taxativamente os casos de extinção de punibilidade. Em nenhum dêles se enquadra a hipótese dos autos. Só poderia alcançá-lo a retroatividade da lei que não mais considerasse o fato como criminoso. Mas a lei que serviu de base à condenação continúa em pleno vigor, não se tendo operado em relação a ela nenhuma das formas de revogação do direito.

JOSE DUARTE, sempre propenso a acolher as sugestões da realidade em face dos fenômenos jurídicos, salienta que na linguagem técnico-jurídica se considera extintiva a punibilidade, quando conservands a ação ou a sua condenação, eficácia intrínseca, surgem causas externas e fora do fato criminoso, que împedem o ulterior desenvolvimento da ação e regras especiais, estranhas aos elementos constitutivos e acessórios do crime, ao ordenamento jurídico, por certas contingências, julga oportuno cancelar o exercício de ação ou deixar inexeqüível a condenação. (Tratado de Direito Penal, Da ação penal, pág. 119).

o pensamento do douto tratadista tem de ser entendido na hipótese de ocorrerem causas permanentes e contínuas, contendo eficácia jurídica capaz de obstar a exeqüibilidade da sentença condenatória.

IPrevalece na doutrina o ensinamento de CARLOS MAXIMILIANO, ao tratar dos casos de revogação de direitos e reportando-se às lições de JAVEIS e COVIELLO:

"Cessam a regra geral e as exceções respectivas quando desaparece o instituto jurídico a que se referem ou torna impossível um fato que era pressuposto necessário da lei. (Hermenêutica e aplicação do direito, número 449 ). 
requereu fossem excluidos do processo quarenta e três indiciados, de molde a prosseguir êle contra dez outros, sete dos quais foran absolvidos, vindo, finalmente, a ser condenados os três exilados drs. Armando de Salles Oliveira, Octavio Mangabeira e Paulo NogueiIRA FILHo.

3. O desfecho, que assim teve o processo n. 1.142 do Tribunal de Segurança Nacional, pôs em singular relêvo o propósito, que o animou. O grande jornal $O$ Estado de São Paulo, de imperecível tradição na imprensa brasileira, que Júlı Mesqurra dirigiu, com sereno desassombro e o mais alto sentimento patriótico, constituía fortaleza da opinião pública, que a ditadura fascista, implantada em 1937, insistia em tomar. Para tal resultado, arquitetou-se, policialmente, o movimento conspiratório de março de 1940. Nenhuma conspiração, sabidamente, existia. Cumpria inventá-la. Inventou-se. Prisões. Simulou-se apreensão de armas de guerra no edifício do, $O$ Estado de São Paulo. Promoveu-se escândalo de publicidade. Não se apurou que, no movimento, estivesse envolvido, ao menos, um soldado

Alegam os ilustres impetrantes que tendo sido a condenação motivada por ataques ao regime e havendo desaparecido os obstáculos à livre manifestação do pensamento, impõe-se a decretação da inexeqüibilidade da sentença.

Como jả ficou acentuado, a lei, que serviu de base à condenação, não foi de qualquer modo derrogada, bem assim continuam vigentes as outras leis coercitivas de atividades consideradas subversivas.

É evidente que a administração pública entendeu conveniente não tornar executáveis no momento certos dispositivos referentes à liberdade de opínião, mas pode depois variar de compreensão e já se anuncia o restabelecimento da censura prévia dos jornais em alguns Estados.

Não me parece consentâneo com os preceitos jurídicos a anulação de sentença condenatória proferida por tribunal competente sòmente porque a autoridade policial tem intermitências de conduta na aplicação de medidas restritivas da liberdade de opinião.

Quanto ao outro ponto do pedido, pode nela deter-se o julgador, sem os embaraços opostos ao anterior.

A história da citação por edital no direito judiciário penal brasileiro mostra que só em circunstâncias excepcionais tem ela de ser admitida.

Não a inscreveu o antigo Código do Processo Criminal. Em substanciosa análise deu o insigne JOÃO MENDES as razões dessa exclusão, concluindo com CÂNDIDO MENDES que em forma de defesa, nula será ab initio a ação criminal intentada contra réu citado por edital.

Códigos estaduais, em consonância com o regime vigente sôbre a elaboração do direito processual, consignaram, essa fórma de citação e a jurisprudência a consagrou em julgamentos pelo júri e em processos de marcha especial. Inseriu-a em termos claros o atual Código de Processo Penal.

Dominou entretanto sempre o princípio de delimitação dessa fórma de citação, aplicada a casos em que o réu não é encontrado ou se oculta ou é incerta a pessoa que tiver de ser citada.

Não podia a justiça ficar tolhida na sua ação corretiva. 
da Fôrça Policial de São Paulo ou do Exército Nacional. Impossível era, portanto, sem o auxilio de fôrças militares, derribar os poderes constituídos. Isso mesmo, de resto, o reconheceu e proclamou a Procuradoria, em termos que não perdem em ser relembrados, antes convém reproduzir para que bem se aquilate a violência, que aos pacientes se fez, e são êstes:

"No apenso II, figuram inúmeros manifestos de autoriá dos drs. Armando de Salles Oliveira e Octavio Mangabeira, apreendidos na Censura Postal, bem assim os envelopes que continham êsses manifestos, sendo de notar que os envelopes enviados pelo acusado dr. Armando de Salles contêm, impressos, o nome de uma casa comercial, ou suposta casa comercial, estabelecida na República Argentina, meio de que se utilizava o remetente ora acusado, que, na sua santa ingenuidade, supunha ludibriar a ação policiai. "Quanto aos manifestos impressos sob o título Á Nação Brasileira, de autoria do acusado dr. Octavio Mangabeira, endereçados a várias pessoas, verifica-se, pelos envelopes apreendidos, que eram

BENTO DE FARIA, sempre claro, acentúa:

"A citação por edital tem lugar não sòmente quando ocorre a incerteza sôbre o lugar onde se encontra o acusado, como também quando o mesmo se oculta ou dificulta o seu encontro" (Código de Processo Penal, vol. 1., pág. 407).

0 respeito pelas fórmas de citação obedece ao principio universal do direito de defesa. Sacrossanto, qualificaram-no MANZINI, GABRIELLI e CONSENTINO.

Não é só o interêsse público qưe está em jôgo, mas caracterizadamente o interêsse do imputado.

Assertou com precisão o Professor VINCENZO MANZINI:

"Assume piu spicatto. rilievo il nesso de relazione tra la sanzione e l'interesse dello Stato alla presenza del citato, e, come abbiamo già avertito, nei riguardi dell'imputato" (Citazione penale, no Nuovo Digesto italiano, vol. $3 .^{\circ}$, pág. 178 ).

O Decreto-lei n. 474 , de 8 de junho de 1938 , que dispõe sôbre o processo dos crimes de competência do Tribunal de Segurança Nacional, prescreve no parágrafo único do artigo $4 .^{\circ}$ :

"A citação será feita pessoalmente se o réu estiver prêso, ou quando sôlto ou foragido, por edital afixado à porta do Tribunal."

0 processo a que responderam e em que foram condenadas as pessoas visadas no pedido obedeceu a êsse dispositivo.

Mas em tôda a evidência não podia ser êle aplicado à hipótese dos autos.

A lei distingue a situação dos réus: sôltos ou foragidos.

Estariam soltos os condenados no presente processo? Parece-me irretorquivel a negativa. Não se achavam êles na situação de plena liberdade nos seus movimentos, podendo regressar ao país sem qualquer risco, hip6tese que a lei caracteriza ao usar da locução empregada. Foragidos? Muito menos. Na técnica jurídica, o têrmo abrange os que fogem deliberadamente, para se subtraírem à ação da justiça.

Achavam-se êles exilados, por determinação da autoridade, em razão de acontecimentos políticos nos quais se haviam envolvido e em lugar certo 
procedentes da República Francêsa, onçe se encontra o acusado como exilado político, por inconveniente aos interêsses de sua Pátria.

"Existe ainda no apenso II, um livro de autoria do dr. Armando DE SAlles Oliveira, habilmente disfarçado com o titulo - Historia de la Australia, Obra premiada por la Sociedad Britanica de Historia Colonial, cujo livro, na realidade, contém 20 manifestos de sua lavra, sob o título - Diagrâma de uma situação política (Carta aos Brasileiros).

"Idênticos exemplares já constam dos diversos volumes dêste processo, apreendidos, em grande escala, pela Censura Postal de São Paulo.

"Eis em traços largos o modo pelo qual os acusados drs. ARmando de Salles Oliveira e Octavio Mangabeira dão expansão, aos seus designios subversivos.

"Frustradas as esperanças de governarem o Brasil, perdida a compostura que deviam manter nos países de asilo, êsses maus bra-

e sabido. Não há como confundir essa situação perfeitamente configurada na prova dos autos, com as situações que a citada lei precisa.

A hipótese dos autos é de delito político por manifestação de opinião. Quando tais delitos se restringem a êsse aspecto, não revestem em regra caráter odioso. Não há neles a nódoa de sangue nem o mercenarismo que disfarça ou avilta supostas ideologias.

Já FERRI na Relação do projeto de 1921 ressaltava que o elemento decisivo é sempre o psicológico e pessoal dos motivos determinantes dos autores do delito, entendendo com estas expressões os motivos e os escopos superiores e diversos dos motivos de vantagens egoísticas e pessoais.

Como recorda ALTAVILla, êsse conceito não é monopólio da Escola positiva, pois MANZINI a êle se associa expressamente.

Embora o julgamento pelo tribunal especial seja feito por livre convicção, a citação em fórma regular proporcionaria ao julgador elementos mais amplos e eficazes, pelos recursos de que os acusados deveriam dispor em defesa própria, articulada de modo direto, e não por via de defensor de ofício, nem sempre apto a apreender todos os aspectos do caso, e a pôr no devido relêvo os motivos da atitude incriminada.

A observância da citação por edital no caso presente opõem-se assim princípios tradicionais de direito e os dizeres expressos do próprio texto aplicado.

Aliás, como o relembrou a petição, o Supremo Tribunal Federal, por decisão unânime, já deu ao parágrafo único do art. $4 .^{\circ}$ do Decreto-lei número 474 , de 1938, a interpretação exata. No habeas-corpus n. 28.872, de Sergipe, de que foi relator o eminente Sr. Ministro LAUDo DE CAMARGO, êste tribunal concedeu a medida liberatória, por entender que o paciente não se achando rigorosamente sôlto nem foragido, não podia ficar compreendido na forma da citação prevista no citado dispositivo.

Nestes têrmos, considerando nulo o processo e em conseqüência a sentença condenatória imposta aos Drs. ARMANDO DE SALES E OLIVEIRA, OTAVIO MANGABEIRA e PAULO NOGUEIRA FILHO, por preterição de 
sileiros, ora acusados, estão grandemente comprometidos na odiosa propaganda de caráter subsersivo contra o govêrno de sua Pátria.

“ $E$ ' profundamente lamentável o que ocorre com êsses acusados e seu companheiro de empreitada, dr. Paulo Nogueira Filfo, já focalizado por esta Procuradoria, no inicio da presente classificação de delito.

"Os seus atos alarmam uma sociedade inteira e por isso mesmo devem ser conhecidos e proclamados como um exemplo perigoso às gerações que vão surgindo.

"Por tudo quanto fica exposto e mais pelo estudo atento de todas as peças do processo, como sejam: buscas e apreensões, várias publicações de caráter subversivo, declarações de acusados, depoimentos de testemunhas e, ainda, pelas circunstâncias em que foram apurados os fatos, chega-se à prova, sem dúvida possivel de ser aceita, de que os delinquentes focalizados por esta Procuradoria, se bem que não concertassem declaramente nenhum plano re-

formalidade substancial, que importou no cerceamento do direito de defesa, meu voto é pela concessão da ordem.

\section{voTo}

O Sr. Ministro Filadelfo Azevedo - Da tradição de nosso direito é que - ausente do distrito da culpa pođe ser citado por editais, quer diante da Ordenação, quer do Código de 1832, a despeito da reserva de JOÁO MENDES, segundo a praxe atestada por GALDINO DE SIQUEIRA (§ 161), PIMENTA BUENO (n.* 180) e PAULA (PESSOA (nota n. 2.727) e reiterada pelos Códigos estaduais de Processo Penal, especialmente o dêste Distrito.

Quando da primeira lei de segurança, votada pelo Congresso em 1935, se dispôs que, não encontrado o acusado, seria citado por editais com dez dias de prazo (n. ${ }^{\circ} 38$, art. 38 , b), regra mantida, com redução para oito dias, no Decreto n. 244 , de 1936 ; no Decreto-lei $n .^{\circ} 474$, de 8 de junho de 1938, se declarou, porém, que a citação seria feita pessoalmente se o réu estivesse prêso e por edital afixado na porta, quando sôlto ou foragido.

o próprio Tribunal de Segurança não aplicou porém, o texto ao pé da letra. (CASTELO BRANCO - Anotaçóes - Pág. 257) e esta Côrte, ainda há pouco, anulou processo, por falta de citação pessoal, quando demonstrada a forçosa mudança do réu em época anterior.

Assim, o réu deve ser citado pessoalmente, quando demonstrada a forcosa mudança do réu em época anterior.

Assim, o réu deve ser citado pessoalmente, salvo ausente do distrito da culpa ou foragido; a mudança posterior ao crime, sem razão fundada, não pode, por isso, trazer vantagem, especialmente quando para o estrangeiro.

Se o delito é praticado, porém, já ao tempo da ausência do País, exigirse-à citação pessoal, mediante rogatória, a que se refere, aliás, o novo Código de Processo Penal (art. 367), quando o lugar for sabido?

Penso que sim, salvo em relação a crimes políticos, em que as rogatórias não seriam cumpridas a pari, do que aconteceria entre nós, ligadas como se acham aos principios que regem a extradição (art. $784, \S 10^{\circ}$ ) e muito menos a publicação de editais no estrangeiro. 
volucionário, pelo menos desta vez, praticaram, contudo, uma série de delitos individuais contra os poderes constituidos.

"Narrados por esta Procuradoria, com perfeita exatidão, os sucessos largamente debatidos pelas autoridades policiais que procederam às diligências, salvando, sem dúvida, ao órgão do Ministério Público, o direito de orientar-se em face das provas que os autos oferecem, devemos acentuar aqui, desde já, que o número dos indiciados, de que nos dão notícia os autos, terá de ficar reduzido ao mínimo, como consequência imeđiata e lógica da inocência da maioria dos acusados.

"Nessas condições, a classificação do delito, pois, passa a ser feita por esta Procuradoria, tendo em vista, não os atos inequívocos, acaso idealizados ou praticados pelos delinquentes, mas os crimes políticos bem caracterizados nas provas dos autos, isto é, crimes formais, que se consumam com a prática do ato incriminado, independente das suas consequências.

Quando hoje o Estado, abandonando o velho princípio da territorialidade da lei penal, reprime atos praticados extra fronteiras, fá-lo ainda com o interêsse declarado de seu processo imediato, ainda que à revelia ou por contumácia.

No regime do Código Penal de 1890, a punição só se daria, nos casos excepcionais, quando o criminoso viesse ao Brasil, espontâneamente ou por extradição.

Já, em 1911, a Lei de Extradição n. ${ }^{\circ}$ 2.416, de 28 de junho de 1911, permitia o processo até pronúncia, inclusive, dos brasileiros, ainda que ausentes da República, que perpetrassem em território estrangeiro, entre outros crimes contra a independência, integridade e dignidade da pátria, ficando o julgamento, todavia, adíado (art. 13).

A nova lei de extradição foi além, seguindo exemplos estrangeiros, para ordenar o processo e julgamento de brasileiros e estrangeiros, ainda ansentes do país, que, em território estrangeiro, praticassem ditos delitos.

0 Código Penal de 1942 destacou nos arts. $4 .^{\circ}$ e $5 .^{\circ}$, as duas hipóteses: a de crimes previstos praticados ou cometidos por brasileiros, quando entrassem os réus no território nacional e a de crimes cometidos no tôdo ou em parte, no território nacional, ou que nêle, embora parcialmente, produziu ou devia produzir seu resultado, os quais serão punidos sem dependência das condições postas no primeiro caso, e bem assim contidos no $n .^{\circ}$ I do art. $5 .^{\circ}$.

Ora, na espécie, tanto o delito em foco fôsse considerado como aqui praticado ou no estrangeiro, ou, ainda na situação a que se refere o art. $4 .^{\circ}$, isto $\hat{e}$, de produzir resultado no país, a incerteza do lugar em que fôssem os réus encontrados, tendo variado, até de país, e a impossibilidade de rogatória, justificariam a citação edital, segundo a letra e o sentido do art. 4..$^{\circ}$ do Código Penal e da Lei $n .^{\circ} 394$, conforme, aliás, desenvolvi, a propósito da ação penal derivada de notícias injuriosas insertas em jornais estrangeiros (Rec. Ext. n. ${ }^{\circ}$ 7.475).

A men ver improcede, assim, o primeiro fundamento do pedido e bem assim, o segundo, eis que só a alteração de direito objetivo poderia influir sôbre a coisa julgada, para tornar a condenação inócua, e não a mera mu- 
"E sem que imponha a necessidade de fazer maiores apreciações sôbre o ocorrido, é procedida a classificação do delito:

1. Dr. Armando de Salles Oliveira, qualificado indiretamente a fls. 490, incurso nos incisos 9 e 13 do art. 3 do decreto-lei $n$. 431, de 18 de maio de 1938, combinado com o art. 5, n. II, letra "b", da consolidação das leis penais;

2. Dr. Octavio Mangabeira, não qualificado, incurso no inciso 9, artigo 3, do decreto-lei acima citado, combinado com o art. 5, n. II, letra "b", da consolidação das leis penais;

3. Dr. Paulo Nogusira Filho, qualificado indiretamente a fls. 490, idem, idem."

Minguou, como bem se vê, a acusação policial: o crime coletivo, que a Superintendência de Segurança Política e Social de São Paulo urdira, afim de se apropriar o govêrno do $O$ Estado de $S$. Paulo, reduziu-se a crimes individuais, pois que nenhum plano verdadeiramente revolucionário tinha sido elaborado. E da dezena de acusa-

dança de fatos ou atitudes, muito menos para ser examinada a espécie por habeas-carpus.

Todavia, conhecendo da hipótese, formei convicção no sentido de que o fato gerador da condenação não constituiria o delito imputado ou que, pelo menos, a sentença condenatória não teria fundamentação necessária, 0 que me levará a reconhecer sua nulidade.

Ao tempo da Constituição de 1934, respeitada a liberdade na manifestação de pensamento, sem dependência de censura, salvo em espetáculos públicos era proibida a

"propaganda de guerra, ou de processos violentos para subver-. ter a ordem política ou social".

o Congresso, ao votar a lei de 1935 , teve de enxertar um princípio mitigador da incriminação dessa propaganda, dizendo no art. 48:

"a exposição e a critica da doutrina feitas sem propaganda de. guerra ou de processo violento para subverter a ordem política ou social não motivarão nenhuma das sanções previstas nesta lei".

Logo a seguir, porém, a mesma Câmara, a despeito de vários protestos, revogou expressamente êsse texto, no art. 19 da Lei $n .^{\circ} 136$, de 1935.

Sem dúvida que a medida era formalmente inconstitucional, mas, em verdade, a supressão do explicativo não alteraria a substância da lei - a propaganda doutrinária continuaria lícita.

Ora o Decreto-lei n. ${ }^{\circ} 431$, de 1938 , aplicado aos pacientes, não alterou. o texto anterior punindo a propaganda com o fim de

"atentar contra a segurança do Estado ou modificar por meios. não permitidos em lei a ordem política ou social".

Não haveria como estabelecer distinção fundamental entre êsse texto* e os reguladores de delitos mais graves v. g. o da tentativa de 
dos, acolhidos pela denúncia em suas malhas, apenas três, que se achavam, de há muito, sofrendo, no exilio, a pena a que o govêrno federal, arbitrária e ilegalmente, os submetera, foram condenados pelo Tribunal de Segurança Nacional. Mostra isso o critério a que obedeceram as diligências policiais, mercê ıdas quais, pessoas do. mais alto conceito, pelas posições que ocupavam, e ainda ocupam, em São Paulo, a despeito de sua inocência, foram presas e processadas, por envolvidas em movimento conspiratório, absolutamente inexistente. Mas urgia, entretanto, que o grande processo, em tôrno do qual se fez o maior estardalhaço, não terminasse, ao menos, sem a condenação de três cidadãos expatriados, cheios de serviços ao pais e indefesos.

\section{GAPITULO II}

\section{A nulidade do processo e da sentença condenatória.}

4. Proferindo sentença, em primeira instância, o juiz Antonio Pereira Braga, que é jurista, suspendeu o julgamento dos acusados

"mudar por meios violentos a Constituição, no todo ou em parte, e a forma de govêrno por ela estabelecida". de 38:

Bastaria a definição de ordem politica, fixada no art. $22, \S 10^{\circ}$, da Lei

“A ordem política é a que resulta da independência, soberania e integridade da União, bem como da organização e atividade dos poderes políticos estabelecidos na Constituição da República, nas dos Estados e nas leis orgânicas respectivas".

Assim, para a condenação de alguém à sombra do art. 3, n. $^{\circ} 9$ da Lel número 431, seria preciso demonstrar-se não só a propaganda, como o intuito ofensivo à ordem política, por meios violentos ou ilegítimos.

Assim, sem apreciar, no tocante, à propaganda, a necessária publicidade, e, em geral, a idoneidade do meio usado, a apuração do dolo, por não bastante a simples culpa, ainda que gerada, v. g. por excitação algo imprudente, e até a própria autoria, não digo dos escritos, mas, o que é mais importante, da sua divulgação autônoma, não em ato público, mas, diretamente, com a remessa a certas pessoas, circunstâncias, aliás, posta em dúvida pelo Juiz PEREIRA BRAGA, a afinal constituindo matéria de fato, estranha ao habeas-corpus, teriamos, ao menos, de procurar o segundo elemento da figura criminal proferida.

No acórdam recorrido há referência à linguagem desrespeitosa aos poderes públicos e a seus agentes, como a indisposição das fôrças armadas com a ordem política do país e a própria provocação, quanto ao terceiro paciente, em cartas particulares, a amigos, para concêrto da futura ação direta, mas nenhum dêsses fatos, capitulados em textos autônomos, determinou aplicação de pena, assim teriam de ser afastados.

Seria, antes, preciso acentuar que os escritos tivessem por fim ofender a segurança do Estado ou modificar, por meios não permitidos em lei, a ordem política. 
drs. Armando de Salles Oliveira, Octavio Mangabeira e Paulo NoGUEIRA Filho, sob o fundamento de que se achavam ausentes do país e, assim, sòmente poderiam ser julgados quando a êle regressassem. Não podia, realmente, ser de outro modo, tanto mais quanto êles se achavam, e ainda agora se encontram, fóra do Brasil, contra suas vontades e interêsses, pois que, sabidamente, foram expatriados por ordem do sr. presidente da República, nos últimos dias de novembro de 1938. Acolhidos pela França, permaneceram em Paris até que, impelidos pelas ameaças da guerra, que afinal estalou, se transferiram para Nova York, de onde se transportaram as drs. Armando de Salles Oliveira e Paulo Nogueira Filho para a grande capital argentina, Buenos Aires, que elegeram para Iugar de seus domicílios de exilados. Ali, como em Nova York, permaneceram os três grandes brasileiros cumprindo pena de tempo indeterminado, sob as vistas de polícias especiais, instituídas pelo govêrno que os deportou.

Sem dúvida, o V. acórdão declara que

"as cartas e manifestos constituem matéria de propaganda contrária ao regime, cuja mudança, por meios não permitidos em lei propugnava abertamente"

ou envolviam:

“ação dissolvente";

"propaganda subversiva da Constituição"; "atentado contra a ordem constitucional".

Também aludiu o aresto ao pleiteado, embora impossivel, apoio das classes armadas, e à viável colaboração de antigos correligionários, que, entretanto, não se manifestaram até hoje, passados cinco anos, demonstrando, assim, a absoluta ineficácia de meios.

Mas, aquelas expressões da sentença não caracterizariam suficientemente o objetivo de alteração da ordem política, devendo mencionar quais os meios, as fórmulas, os planos propostos para atingir aquêle resultado.

Eossível que das cartas e manifestos isso constasse, e até outros propósitos, não pròpriamente dirigidos contra a ordem política, mas de caráter pessoal; tudo, porém, teria de ser especificado e não apenas referido em frases vagas, como as que acabamos de citar.

Poderia, por outro lado, faltar o animus necessário, envolvendo os documentos apenas a expansão de sentimentos dos que se viram contrariados em atitudes politicas ou obrigados a uma expatriação penosa e prolongada, como bem acentua a petição inicial.

Não conheço o teor dos documentos, mas não importaria fazer em habeas-corpus o exame de seu conteúdo, tarefa que caberia aos juízes de mérito.

Se envolvessem mera expansão de sentimentos pessoais ou de críticas, ainda que vivas, à nova ordem de coisas, não poderiam, ao menos por extensão ou interferência, justificar a aplicação da lei penal, pois a cláusula explicativa da Lei $n .^{\circ} 38$ continuaria, a meu ver, implícita em face da própria Constituição de 1937 e na ausência de texto expresso em contrário não 
5. Que se acham os três, e ademais dêles outros cidadãos brasileiros exilados por ato do govêrno, e entre êles Paulo Duarte, com êles deportado em 1938, mais Luiz Piza Sobrinho, estando êste em Buenos Aires e aquêle em Nova York, não há duvidar. E' público e notório. Tempo houve em que o govêrno da República, expatriando os seus desafetos, assumia a responsabilidade de seus atos, expedindo decretos determinantes de tal medida. Foi no em que ocupou a presidência o Marechal Floriano Perxoto. No regime fascista, implantado em 1937, atos de tal porte se praticavam, e praticaram-se, clandestinamente. Foram todos intimados, verbalmente, pela Superintendência de Segurança Política e Social, a retiraremse do pais, dentro de prazo exiguo. Tal como na Itália mussoliniâna. No caso, porém, prova existe do expatriamento dos pacientes.

No tópico, já transcrito, da denúncia do Sr. Procurador-adjunto ao Tribunal de Segurança Nacional, afirmou êle, quanto ao Dr. Octavio Mangabeira, que êste se encontrava na República Francesa, "como exilado, por inconveniente aos interêsses da sua Pátria",

bastando para afastá-lo o raciocínio indireto, decorrente de supressão, ainda que intencional do proceito em plena vigência do pacto de 16 de julho.

Ao revés, o texto de 10 de novembro manteve a livre manifestação do pensamento, salvo limites prescritos em lei, que poderia adotar a censura da imprensa, do teatro, do cinematógrafo da radiodifusão, mas sòmente no estado de emergência, excepcionalmente estender a censura à correspondência e a tôdas as comunicações orais e escritas.

Assim, e ao menos até a adoção de texto expresso, nã̃o verificada, a exposição e crítica de doutrina, ainda que de caráter político, ou através mesmo de processos permitidos na Constituição, que continha fórmula para receber modificações oportunas, além de am referendum popular, não poderiam em princípio, constituir atos criminosos; seria preciso que se demonstrasse abuso ou excesso, precisando-se qual a ofensa à ordem política e como deveria ser ilegitımamente alcançada através da propaganda enxergada na remessa de cópias de documentos. Os delitos de opinião de qualquer modo, exigem interpretação restrita, quando não afetam a integridade do país.

Pelo exposto, por ora considero apenas não fundamentado o acórdão do Egrégio Tribunal de Segurança Nacional e, de acórdo com os precedentes por mim várias vezes apoiados, tenho a condenação por nula e, assim, concedo a ordem impetrada.

\section{voTo}

o Sr. Ministro Goulart de Oliveira: - 0 pedido assenta em dois fundamentos básicos: $-1 .^{\circ}$ ) - A nulidade do processo e sentença $-2 .^{\circ}$ ) A injustiça, e inexeqüibilidade da sentença.

Começarei pelo $2^{\circ}$ ) - Os impetrantes procuram dar relêvo a um problema de vigência de leis, e dêle tirar efeito, a meu vêr, sem apôio legal, sem apôio doutrinario, e até certo ponto subversivo.

Não cabe na esfera do habeas-corpus indagar da justiça ou injustiça do julgamento e acreditamos que a asseveração nêsse sentido haja sido feita 
e' quanto aos três, censurou-os por haverem perdido a "compostura que deviam manter nos países de asilo".

Eis, pois, comprovado o exílio forçado dos três cidadãos brasileiros.

6. Expatriados, com residências conhecidas em Nova York e em Buenos Aires, fàcilmente teriam sido citados, se houvesse o propósito de assegurar-lhes o direito de defesa, para que a apresentassem no processo que se lhes intentou, e foi o de n. 1.142, perante - Tribunal de Segurança Nacional. Bem e avisadamente agiu, dessarte, o juiz de primeira instância, suspendendo o julgamento dos acusados até que retornassem ao país. Divergiu, porém, aquêle Tribunal e, pelo acórdão proferido, em 3 de setembro de 1940, na apelação n. 565, decidiu que voltassem os autos à instância primeira, para que fôsisem julgados os três exilardas politicos.

E assim decidiu,

"considerando que o Meritíssimo Juiz da 1.a Instância, prolator da sentença apelada, suspendeu o julgamento dos acusados Armando

apenas como ressalte e moldura ao quadro esboçado, em seguida, com os retraços e tintas de inexeqüibilidade da sentença proferida.

Convém os impetrantes em que o Tribunal de Segurança - tribunal político - cujos juizes podiam julgar por sua íntima e secreta convicção divisou no caso a prática do crime político - e condenou os pacientes.

Convêm igualmente em que há mudança da ondem política - que preconizam - porque sé abriu o debate em tôrno do sistema político e administrativo do país.

$E$ com isso, se tornou repugnante ao sentimento de justiça, ofensivo à eqüidade, que se considere agora, crime o praticado pelos pacientes, quando outros podem fazer o mesmo que êles fizeram...

Transformada a ordem política os mesmos atos que se reputavam antes criminosos, transformaram os delinqüentes, em beneméritos, senão em heróis.

As afirmações com o seu cunho de verdade alicerçada na experiência $\bullet$ na tradição histórica não refletem, entretanto, o momento histórico.

Firmada a petição do remédio buscado por homens do Direito, educados no respeito às leis, o seu subconsciente revelou-lhes a convicção: "Em vigor técnico a lei sòmente por outra lei se revoga ou derroga. -- 19 - A citação de HAUS - (lê - fls. 3).

Não há fazer desaparecer a fôrça obrigatória dos textos legais com o fato de se haver legislado torrencionalmente, em enxames, nem porque haja leis que não chegaram a ter aplicação nem ainda porque há leis dispares da consciência do maior número!...

A invocação de BINDING não aproveita a hipótese...

$O$ desuso do texto não importa por si na sua abrrogação... 0 autor fala da impotência do legislador para conservar a lei.

A mudança da ordem política preciso é se realize efetivamente e se sancione pelos processos resultantes da tradição histórica: legitimidade da origem e consumação do fato. 
de Sales Oliveira, Ogtavio Mangabeira e Paulo Nogueira filho, sob o fundamento de que se acham ausentes da República, e, assim, só poderão ser julgados quando regressarem ao país, conforme a interpretação que a mesma sentença deu ao art. 5 , $\$ 1.0^{\circ}$, da consolidação das leis penais; mas,

"considerando que, na justiça especial, o caso é regido, não pela referida consolidação, mas pelo decreto-lei n. 474, de 8 de junho de 1938, cujo art. 4 , $\S$ único, só exige a citação pessoal para os réus presos, determinando em relação aos demais - soltos ou foragidos - que se a faça por edital afixado à porta do 'Tribunal;

"considerando que, por fôrça do mesmo decreto-lei, entre os réus soltos, o Tribunal tem entendido que se encontram os ausentes em paises estrangeiros, e, assim, os tem julgado, independentemente de seu regresso ao Brasil;

"considerando que essa situação não traz ao réu sôlto qualquer prejuízo, de vez que póde constituir advogado, e, se o não fizer, não poderá o juiz julgá-lo, sem lhe nomear defensor;

Se os próprios fenômenos de fato, resultados das revoluções vitoriosas têm sagrado definitivamente o respeito às situações discricionárias dos ditadores, predominando sôbre tudo a razão do interêsse público como suprema legitimação dos seus atos, como exigir do Juiz a decretação de inexistência de sentença passada em julgado, proferida por Tribunal competente, calcada em lei em plena vigência, ao temipo da condenação, como ao tempo da provocação do remédio extraordinário?

Cabe habeas-corpus, na verdade, quando o fato por que hajam sido condenados os pacientes não constitua crime. Os impetrantes fazem decorrer essa asserção da afirmação da mudança da ordem política - de que resultou não se considerar agora crime aquilo por que foram condenados os pacientes.

A lei em que incidiram êles, na convicção dos juizes que os julgaram, dentro da sua competência, não foi revogada por outra lei. Permanece em inteiro vigor.

Este Tribunal é chamado, assim, a decretar por um aresto seu fatos que excedem à sua competência: - a mudança da ordem política nacional e a conseqüente impunidade dos réus de crimes que essa mudança porventura venha acarretar.

Daí considerar eu subversiva a proposição.

Quanto ao $10^{\circ}$ argumento, já deixei manifestada a minha opinião. Não tomei parte no julgamento de que se fêz menção. Nêle se declara que o Sr. Ministro CASTRO NUNES e eu não estávamos presentes. Foi o caso que teve como relator o Sr. Ministro LAUDO DE CAMARGO e que teve a solução apontada. Entretanto, no julgamento de hoje, de que fui relator, manifestel a solução que teria dado, se estivesse presente, naquêle outro.

Em relação a esta conclusão que adotei, no ponto abordado, que reveste até certa altura, no primeiro fundamento do atual pedido de habeas-corpus, já ficou manifestada a minha opinião, que completo, agora: ou se considera o delito praticado dentro do Brasil - e - nêste caso, a solução seria aquela que dei no habeas-corpus de que fui relator - ou se terão considerado os pacientes dêste processo como tendo ultimado o crime fora do país, e, nêste caso, não se poderia, na situação em que se achavam, considerá-los 
"considerando que aos réus ausentes foi dado advogado". Tornou-se o processo, dessarte, radicalmente nulo.

7. Era indispensável a citação pessoal dos acusados, porque êles não se encontravam, absolutamente, na situação prevista no § único do art. 4 do decreto-lei n. 474 , de 8 de junho de 1938. "A citação", nêle se lê, "a citação será feita pessoalmente, se o réu estiver prêso, ou, quando sôlto ou foragido, por edital afixado à porta "do Tribunal". Soltos, evidentemente não se achavam. Tem o vocábulo sentido próprio. Refere-se aos acusados que se podem locomover livremente, sem coação de nenhuma espécie, e livres de qualquer violência ou arbítrio; mas, entenda-se bem, dentro do território nacional. Exilados e impossibilitados, ao tempo, de regressarem a seus lares e afazeres, porque dêles violentamente expulsos por determinação do Presidente da República, não poderiam considerar-se soltos, no verdadeiro sentido da palavra. Exprime os que se achem livres de prisã̃o, de cadeia. Os que não estão sujeitos a nenhuma pena, ou constrangimento em sua liberdade. Podiam ha-

réus foragidos, e, então, a solução, ainda assim, seria a de concessão da ordem, na forma do voto do Sr. Ministro Relator.

Concedo a ordem.

\section{VoTo}

o Sr. Ministro Waldemar Falcão - Sr. IPresidente, invocando o art. 643, ns. VI e VII, do vigente Código de Processo Penal, dois são os fundamentos principais do presente pedido de habeas-corpus: é um dêles a extinção da punibilidade em que foram considerados incursos os pacientes; é o outro, o fato de estar nulo o processo por lhe faltar um têrmo substancial, ou fôsse a citação dos acusados.

Examinarei em primeiro lugar o fundamento relativo à extinção da punibilidade. Repousa êle, na linguagem dos doutos impetrantes, no fato de que, alterado o panorama político do Brasil, mudada em seus lineamentos essenciais a passagem dos acontecimentos sociais, em nosso meio, estaria desaparecido claramente o motivo inspirador, estaria desaparecida, igualmente, a razão de ser, a explicação mesma da condenação sofrida pelos pacientes.

Condenados por crime político, sofreriam os pacientes, até o momento dessa mutação as condições inerentes àqueles que não inculpados de atos ou fatos julgados inconvenientes à estrutura do Estado e, por tal, passíveis de punição. Não preciso recondar ao Tribunal a complexidade do conceito do crime político; como êle se dilui, se distende, se transforma através dos tempos. E' mesmo umą contingência histórica inelutável. Seja êle encarado dentro do critério puramente subjetivo, seja êle encarado pelo chamado critério objetivo, seja ainda compreendido simultâneamente pelos dois critérios, como ainda agora, contemporâneamente se observa, êle, é, ainda assim, uma resultante, uma conseqüência da evolução mesma das sociedades, da transformação dos fatos políticos, da maior ou menor repercussão que êsses. fatos possam ter na consciência dos legisladores.

Mas, Sr. Presidente, caberá ao Juiz, no Tribunal, caberá ao Magistrado, no Pretório, sentir essas ressonâncias dos fatos políticos, ver nos fatos, en- 
ver-se como soltos cidadãos expulsos de sua Pátria, sumàriamente, sem a mais minima figura ou simulacro de processo? Se soltos, no sentido jurídico da expressăo, não estavam, porque banidos do país, poder-se-iam, acaso, reputar foragidos? Não se consideram tais os fugidos por crimes, os homisiados? Os escondidos e errantes, para escaparem à justiça? Homens digníssimos e capazes de arcar, como sempre fizeram, com as responsabilidades dos atos de suas vidas públicas, não fugiriam a elas. Não fugiram. Não se exilaram. Não eram foragidos. Mas exilados, deportados, banidos, sem culpa, nem pena!

Não podiam, em condições tais, especialíssimas, ser julgados, nem processados, sem que regressassem ao seu país ou, ao menos, sem que tivessem sido citados pessoalmente, para que pudessem receber suas notas de culpas e defenderem-se cabalmente.

8. Muito não há, pois foi por acórdão de 3 die dezembro de 1944, proferido nos autos do habeas-corpus n. 28.872, do Estado de

tão apontados como crime e hoje apontados como atos normais, elemento capaz de afastar inteiramente a conceituação criminosa dêsses fatos?

Certamente essa é a função dos sociólogos, do legislador, do estadista.

Quando o nosso Código de Processo Penal e quando o nosso Código Penal admitem a abolição da pena pela extinção da punibilidade: quando, por exemplo, o nosso Código Penal, no seu art. 108, parágrafo único, prevê a possibilidade dessa exaustão do delito pela extinção dessa punibilidade, quando ainda, no art. $20^{\circ} \mathrm{e}$ em seu parágrafo único, o referido Código diz:

"Ninguém pode ser punido por fato que lei posterior deixa de considerar crime, cessando em virtude dela a execução e os elementos penais da sentença condenatória": quando acrescenta no parágrafo único:

"A lei posterior, que de outro modo favorece o agente, aplica-se ao fato não definitivamente julgado e, na parte em que comina pena menos rigorosa, ainda ao fato julgado por sentença condenatória irrecorrível": quando assim falam as nossas leis vigentes logo se vê que constituem elas um imperativo para a consciência do julgador, eis que, em se verificando essas hipóteses, em so concretizando essas cỉrcunstâncias, êle não poderá mais condenar o acusado por um fato que se enquadra nessas provisões legais.

Mas, na presente hipótese, em que pese a argumentação tão interessante dos impetrantes, não vejo como configurar essa conjuntura legal.

Por mais que se transformem os aspectos polfticos e sociais do mundo contemporâneo, ainda êsses aspectos não tiveram até o presente - ao que conste ao Supremo Tribunal Federal - a ressonância capaz de abjetivar uma norma legal, que se imponha à consciência do julgador como um imperativo do seu dever.

E' por essa circunstância que, não estando, a meu ver, extinta a punibilidade dos pacientes, não posso dar o habeas-corpus com o fundamento que em primeiro lugar abordej.

Resta examinar o segundo fundamento: a nulidade do processo por falta de um têrmo substancial - a citação dos acusados.

O Decreto-lei n. ${ }^{\circ} 474$, de 8 de junho de 1938 , em seu art. $4 .^{\circ}$, parágrafo único, previu a hipótese da citação do acusado por edital. 
Sergipe, impetrado pela advogada Dra. Maria Rita Soares de ANDRAdE, o Egrégio Supremo Tribunal Federal houve por bem conceder a ordem, declarando nulo todo o processo em que o, Tribunal de Segurança Nacional oficiou, condenando o acusado não citado pessoalmente a um ano de reclusão. "Essa penalidade", lê-se na certidão do julgado e seu relatório, "essa penalidade foi imposta pelo Tribunal de Segurança Nacional. Mas, a sua imposição, se deu em processo radicalmente nulo, por falta de citação do paciente, que, citado fôsse, com facilidade desfaria tôda a ação".

Dando seu voto, favorável ao recurso, salientou seu revisor, o sr. ministro LaUdo dE Camargo, ser certo que a lei fala em réu prêso; mas, obtemperou, "o legislador teve em vista que, nestas condições, conhecido o lugar em que se encontra o acusado, possivel não seria deixar de citá-lo pessoalmente. E, nos demais casos, evitando delongas processuais, a citação por edital tudo resolveria. Ora, o convocado estava servindo em lugar certo, conhecido do comando, segundo informou, e conhecido igualmente do juiz. Estava nas

Obedecendo, em linhas gerais, à tradição do Direito brasileiro, que sempre exigiu, sobretudo em matéria penal, a citação pessoal do acusado, não poderia o legislador de excepção desprezar êsse principio.

E, por isso mesmo, no seu art. $4 .^{\circ}$, estabeleceu que o Juiz do feito mandará incontinenti citar os réus para defender-se e constituir advogado, dentro em 24 horas; nomeará defensor para os que o não apresentarem - concederá à defesa vista dos autos, em cartório, pelo prazo de 48 horas.

$\mathrm{E}$ acrescentou, no parágrafo único:

"A citação serão feita pessoalmente se o réu estiver prêso ou, quando solto ou foragido, por edital afixado à porta do Tribunal".

Vê-se que abraçou o Decreto-lei $n .^{\circ} 474$, de 1938 , essa alteração que já se vinha notando no Direito Processual Penal, no sentido de admitir e acolher a possibilidade de citação edital de acusado, hipótese que, anteriormente, na vigência do velho Direito Processual Criminal do Império, não era admitida.

Foi por isso que se imaginou, no presente caso, ser perfeitamente legal a citação edital dos acusados no processo.

Mas, estariam êles enquadrados na hipótese prevista pelo legista de excepção?

Seriam êles réus soltos ou foragidos? Ou estariam êles numa situação especial, que demandaria uma forma diferente de citação, de acôrdo com a tradição mesma, com a fisionomia característica do Direito Processual Penal brasileiro?

Vê-se do processo, lê-se na denúncia mesma do Procurador do Tribunal de Segurança Nacional, que os acusados teriam praticado o delito, de que são inculpados, precisamente por se acharem exilados do seu país e à sombra do asilo que lhes teriam concedido outras nações.

Nestas circunstâncias excepcionais de sua vida de homens públicos, êles teriam sido levados a propagar idéias, a divulgar conceitos, a distribuir panfletos, que importariam em subversão da ordem constitucional vigente do Brasil. 
mesmas condições daquêle que estivesse prêso, para gosar da medida, dadas as restrições com que contava. Não se deve interpretar a lei contra a sua finalidade e o seu espírito. $E$ o espirito do texto. do $\S$ único do rt. $4.0^{\circ}$ do decreto-lei n. 434, de 33, está a mostrá-lo com clareza". Assim argumentou o grande juiz. Não viu "como dispensar a citação pessoal de quem de plena liberdade não contava. A falta de citação viciou, pois, de nulidade o processo e acarretou prejuízo à defesa, conforme alegação feita". E deferiu o pedido. No mesmo sentido manifestou-se o sr. ministro Orozimbo Nonato. A seu crer, o relator "interpretou muito bem o dispositivo que permite a citação por éditos, mas de réu sôlto ou foragido. Foragido, não estava o réu, no caso presente; é exato, também, que não era encarcerado, mas estava em situação idêntica, para o efeito de se defender em processo". No mesmo ponto de vista se colocou o sr. ministro Bento de Faria.

E a ordem de habeas-corpus foi unânimemente concedida, impedido o sr. ministro Barros Barreto, ausentes os srs. ministros

Logo, da própria descrição do delito feita pelo representante do Ministério Público no Tribunal de Segurança Nacional se vê que é da essência mesmo do crime inculpado aos pacientes a sua ausência, dêles acusados, do país; e, da circunstância da ausência, surgiu a possibilidade de, da própria terra estrangeira, terem querido insinuar entre concidadões seus a alteração da estrutura mesma do Estado Nacional, vale dizer, do regime político de seu país.

Ora, se assim era; se assim entendia o Ministério Público; se êle sabia que não estavam os pacientes perambulando livremente no país, e que, ao invés, estavam êles compelidos a uma situação outra, que não a de sua existência normal; e se era sabido, até mesmo pela colheita dos elementos informativos do crime, o ponto exato do território estrangeiro onde se encontravam os acusados e de onde teriam partido os papéis subversivos, tudo indicava a conveniência de ser observado êsse mandamento legal dơ Direito Brasileiro: a citação pessoal do acusado, mandamento que domina principalmente no Direito Penal, e que não pode ser postergado de modo nenhum quando se imputa ao cidadão uma acusação que dá azo a uma conseqüência punitiva.

Trata-se, pois, de uma preceituação que não pode ser abalada, quando se trata de liberdade individual.

Foi êsse mandamento que não foi observado.

E não o foi, porque a citação edital foi posta em prática numa circunstância de que, dispondo o Regimento do Tribunal de Segurança Nacional, que se daria o prazo de 48 horas para a citação-edital, não se poderia, de modo algum, admitir a hipótese de que cidadãos brasileiros, ausentes do seu país compulsòriamente, pudessem acorrer ao chamamentó a Júzo e viessem aqui defender os seus direitos, em tão estrito prazo.

E', pois, dentro dessa conviç̧ão que eu, ainda, me permito recordar que se bem não fôsse rigorosamente igual, à hipótese ventilada na petição do habeas-corpus ora em aprêço, se bem que não seja êste caso idêntico. ao que se julgou, aqui, no Tribunal, de referência ao habeas-corpus n.* 28.872, de Sergipe, há entre êle e o atual caso aparéncias e semelhancas. 
Castro Nunes e Goulart de Oliveira, sendo declarado nulo o processo, por falta de citação pessoal do acusado.

9. Nem se argumente, nêste trânse, com o preceito do art. 17 do decreto-lei n. 394, de 28 de abril de 1938, de poderem ser processados e julgados, ainda que ausentes, brasileiros e estrangeiros que, em território estrangeiro, perpetrem crimes contra a existência, a segurança ou integridade do Estado e a estrutura das instituições; e contra a economia popular. Não se argumente com êle, por duas razões. A primeira é a de não dispensar a ausência, no sistema do direito brasileiro, a citação do acusado, que importaria em cercear-lhe, senão em sacrificar-lhe a defêsa, tornando-a quiçá impossivel. A segunda é a de ter sido aquêle preceito derrogado pelo do art. $4 .^{\circ}$, $\S$ único do decreto-lei n. 474 , de 8 de junho de 1938, a que o Egrégio Supremo Tribunal Federal emprestou singular relevância no acórdão de 13 de dezembro de 1944 .

que o situam esta última dentro da jurisprudência adotada naquele caso por êste egrégio Tribunal.

Naquele, havia um acusado, que tinha sido convocado para o Serviço Militar e estava, por fôrça dessa convocação, em lugar que deveria ser conhecido pela autoridade judicante; neste, não há um acusado convocado para o Serviço Militar, mas há brasileiros que foram obrigados, por circunstâncias que não vêm a pêlo apreciar, mas que decorrem de ato de autoridade pública, o se ausentarem do país e a permanecerem no estrangeiro.

Não poderia, por conseguinte, a autoridade judicante ignorar esta circunstância, lícito não seria omitir a formalidade essencial da citação pessoal dos acusados.

Isso pôsto, e fiel ao ponto de vista que adotei naquele caso, dentro da orientação do respeito ao principio de coerência, que sempre procuro manter neste egrégio Tribunal, sou levado a acompanhar o voto do sr. Ministro Relator, concedendo o habeas-corpus nos têrmos e para os fins do voto de S. Exia.

\section{voTo}

o Sr. Ministro Orosimbo Nonato - Sr. Presidente, com três argumentos lidam os impetrantes na fundamentação do presente habeas-corpus. Refere-se o primeiro à ausência de citação dos pacientes que, exilados, por determinação do Govêrno, não podiam ser considerados "soltos" ou "foragidos", hipótese única em que bastaria a citação por éditos. Ninguém deve ser processado incônscio da acusação e sem possibilidade de responder às capituladas do M. P.

Alude o segundo à injustiça da sentença.

o terceiro diz respeito à generalização, na consciência jurídica do país, de um estado de espírito incompativel com a punibilidade do fato por que foram os pacientes condenados, faltando, a essa conta, clima vital para a execução da sentença. Ocorreu o fenômeno a que UNGER denominou "mitígação da relação jurídica", dependendo a eficácia da lei, conforme o magistério de LASKY, menos da fonte de que derive do que de sua aceitação e generalidade. Deixou o fato de ser considerado crime pela consêência pública, e com tal e irresistivel veemência, que é êle agora pra- 
Haveria a considerar se aquêle dispositivo fôsse admissível e aplicável ao caso, o que se contesta, que, condenados os três insignes brasileirọs por infração do art. 3.o, n. 6, do decreto-lei n. 431, de 18 de maio de 1938, o crime, que se lhes imputou, sòmente poderia cometer-se no território brasileiro. Pune-se ali, realmente, com a pena de 2 a 5 anos de prisăo, "fazer propaganda ou ter em seu poder, em sua residência ou local onde deixar escondida e depositada, qualquer quantidade de boletins, panflêtos ou quaisquer outras publicações" contra a ordem política, naquêle diploma définida. Aqui, portanto, onde os boletins, manifestos ou panflêtos, se distribuiriam, é que o crime seria praticado. Dentro do território nacional. Não no estrangeiro. Tanto que teriam sido apreendidos pelas autoridades policiais brasileiras e encontrados em poder de brasileiros, dentro do Brasil.

ticado, às declaradas, e sem o esbôço, sequer, de qualquer tentativa de repressão.

Tais, em sintese apertadíssima, os fundamentos do pedido.

Reiegado de plano o segundo fundamento - injustiça da sentença inexaminável em habeas-corpus, considerei o terceiro para negar-lhe assentimento. Convenho em que não guarda qualquer ligação com o caso dos autos o art. $3 .^{\circ}$ do Código iPenal que versa a ultratividade da lei excepcional ou temporária. Teve em mira o legislador, quanto à lei excepcional, que se não confunde como sàbiamente, adverte BENTO DE FARIA (Cód. Pen., vol. II, n..$^{\circ}$ II) àquela determinada por fato extraordinário. Mostram-no os exemplos de SALTELLI DI FULCO, invocados pelos exegetas da nossa lei penal (brigantaggio, tempo di guerra, stato di assedio, terremoto, epidemia e simili). E, ao aludir à lei temporária, visou aquela que se destina a reger situação durante certo período de tempo ou durante a permanência de certo acontecimento (vêde JORGE SEveriano, Com. ao C. Penal, P. Geral, I, pág. 239). Em rigor e vistas ao longo da história, temporárias são tôdas as leis que traduzem o direito positivo, e que passam com o mudar das instituições - o dobrar dos tempos. Tôdas elas se estubelecem do precário, do finito, do perituro das criações humanas, que inspiraram as "tremendas palavras" de MEFISTÓFELES e a que se refere OERTMANN "sucedem-se as leis e os direitos como um mal eterno". Muito mais estreito, porém, foi o ângulo visual do legislador, ao enunciar o princípio do art. $3 .^{\circ} \mathrm{e}$ ao referir-se à lei transitória, que é a que se destina à vigência temporária" (art. 2.0 da Lei de Introd. ao Cód. Civil).

Não é o caso dos autos. E o asserto desenvolvido pelos impetrantes quanto à ineficácia da lei penal, por ausência de ambiente na própria consciência jurídica do povo, tem a contrastá-lo obstáculo insubordinável: o princípio de que a lei vigora até que outra a modifique ou revogue (art. 2.0 da lei de Introdução). O "cessante ratione legis cessat ipsa lex" não foi invocado no pedido. $\mathrm{E}$, na real verdade, não lhe traria alento $\mathrm{e}$ esfôrço. No caso mesmo em que a lei penal tem sua permanência subordinada à permanência de certo acontecimento ou situação, opina JORGE SEVERIANO que a autoridade apta a reconhecer como cessadas as circunstâncias que determinam a lei é o legislador mesmo, verbis:

"Sòmente quem faz a lei é que tem o poder de revogá-la, todo ou em parte. Entre as atribuições do Poder Judiciário 
Tanto assim foi, de resto, que o juiz Antonio Pereira Braga, por sentença de 4 de dezembro de 1940, ao depois reformada, absolveu os acusados da imputação que se lhes fez,

"considerando que, relativamente ao acusado ARMando DE SALLES Oliveira, se a seu - Diagrama de uma situação politica, impresso em Nova York, era remetido de Buenos Aires, não haveria senão méra presunção de ser êle quem o remetia, pelo correio, se provado ficasse estar nessa cidade ao tempo em que foram lançados às caixas de coleta;

"considerando que, semelhantemente, o fato de o manifesto do acusado Octavio Mangabeira, impresso em Biarritz, ser lançado, ao correio, em Pau, apenas deixaria presumir ser êle quem o remetia, se provado ficasse estar neste lugar, ao tempo de serem entregues no correio;

(Const. Fed., arts. 99 e segs.) não encontramos a de revogar leis... ao juiz não é possível absolver alguém colhido nas malhas de uma lei especial ou temporária, só porque a ela deva parecer que as circunstâncias que a determinaram já não existem" (liv. cit. pág. 238).

E o asserto é verdadeiro quanto às leis a cláusula de emergência pura o simples:

OSCAR TENORIO:

"Leis temporárias existem que não dependem de têrmo e condição. Contém a cláusula de emergência pura e simples. Enquanto o poder legislativo não revogar a lei, considerando expressa ou implicitamente desaparecido o periodo de emergência, surtirá efeitos, terá eficácia. Por isto, não se catalogam, rigorosamente, entre as leis temporárias. (Lei de Introdução, $\left.n .^{\circ} 45\right)$.

Mas, o problema não foi enterreirado pelos impetrantes nêsse terreno, que seria deveras impróprio e nem o cessante ratione legis foi invocado caso em que útil seria o adminículo de lições de ESPfNOLA e ESPfNOLA FILHO, PAULO DE LACERDA, CHIRONI e ABELO, ALVES MOREIRA, TEIXEIRA DE ABREU e tantos outros. E nem se abre perspectiva para a controvérsia referente à possibilidade de revogar-se a lei pelo seu desuso.

o problema que os ilustres impetrantes propõem é outro, e ainda mais grave: é o da possibilidade de se declarar revogada certa lei pela mudanca das circunstâncias que a inspiravam e que levam ao espetáculo de sua inaplicação. Tenho que não pode o Juiz, em tais casos, declarar a invalidade da lei. Constitui verdadeiro ius receptum que a lei só se revoga por outra, em linhas de princípio. O seu desnível com a opinião pública e a sua mesma desaplicação não autorizam o juiz a declarar-lhe a ineficácia e a morte. No combate às leis injustas, mas vigentes, a posição do juiz não é na vanguarda, pois não lhe cabe a função de legislar. 0 que lhe compete é interpretar humanamente a lei e eleger, entre os vários sentidos que a ela ofereça, o mais conforme ao bem público e a eqüidade. Seria subversivo, entretanto, dar-lhe o preceito de declarar sem vigência 
“considerando que, relativamente ao acusado Paulo Nogueira FilHo, os seus manifestos, impressos em Paris, foram lançados ao correio no Brasil, como se vê a fls. 390, o que nem aquela presunção deixa estabelecer".

10. Seja qual o ângulo por que se examine o processo, ressalta sua nulidade, decorrente da falta de citação pessoal dos acusados. Existisse, no plano jurídico, a carta totalitária de 1937, em face dela se não poderia justificar texto que suprimisse a citação pessoal dos acusados, para que tivessem ciência da nota de culpa e pudessem defender-se. Pelo estabelecido por ela no art. 122, n. 12, in fine, "a instrução criminal será contraditória, assieguradas, antes e depois da formação da culpa, as necessárias garantias de defesa". Entre elas, e como principal, sublima, antes da formação da culpa, a citação pessoal do inculpado. Intuitivo é isso. Intuitivo e essen-

lei não revogada. Se entre a lei e o sentimento público abre-se discordancia profunda, cria-se um problema angustioso, mas cujo desate compete ao legislador, e não ao juiz.

Quanto à inaplicação prática da lei, apregoar doutrina contrária é incidir ao êrro a que se refere TEIXEIRA DE ABREU: o de misturar aplicação com vigência da lei, quando o primeiro é o registro de um fato e o segundo contém um conceito de direito.

0 prisma do juiz é o do jurista técnico: a razão da cbrigatoriedade de um preceito de direito radica-se na ordem juridica positiva a que ela pertence: para êle é obrigatório "todo aquel que con arreglo a las notas positivas estabelecidas en el ordenamiento vigente ostenta los caracteres de tal" (RADBRUGK, in Sichs, Direcciones Cont. del pens. jur., pág. 191).

CAPITANT, apesar de referir-se como a corpus mortus, às leis cujo conteúdo de utilidade, em conseqüência das transformações sociais, esvaziou-se às completas, mantém, como princípio, o de que la loi, une: fois promulguée, reste en viguer tant qu'elle n'a pas été abrogée par une loi posterieure”.

E acrescenta o claro professor francês:

"C'est au legislateur qu'incumbe Ja mission de remplacer une règle viellie et surannée par une autre, mieux appropriée aux conditions économiques actuelles. Le caractère de certitude, qui est le signe distintif de la loi et en fait un mode perfectionné de production juridique, exige que la force obligatoire de la loi ne puisse être discutée en aucun cas, quand meme ses dispositions seraient devennues gênantes ou inutiles". (Introd., n..$^{\circ}$ 50).

Argumenta-se, porém, que, no caso, a mudança de circunstâncias retirou a lei o seu princípio de vida. Se aquela mudança se caracterizasse pelo estabelecimento de um novus orde legal incompatível com a lei, caso seria, de certo, de revogação tácita. Quando, porém, como na hipótese, não há revogação implícita, virtual, o que prepondera é o princípio enunciado em SALVAT:

"La ley subsiste en todo su vigor, aunque no reciba aplicación prática por el cambio o la desaparición de las circuns- 
cial. Nem se póde ter instrução contraditória onde e quando o acusado, por ignorância da denúncia ou do libelo, de que não teve ciência, impossibilitado se depare de contraditar...

\section{CAPITULO III}

\section{A injustiça e inexequibilidade da sentença condenatória dos três exilados.}

11 Não apenas ilegítima, por proferida em processo absolutamente nulo, mercê de preterição de formalidade substancial, qual a da citação dos acusados, não efetuada legalmente, é a sentença que condenou os três exilados brasileiros. Também injusta se teria de haver, se de manifesta nulidade não fôsse. Juntam-se a esta petição exemplares dos manifestos ou panflêtos, que serviram de base

tâncias que la dieran nacimiento". (Der. Civ. Arg., Parte Cen., n. 324 in fine).

E' que a obrigatoriedade da lei não provém das razões, que a inspiraram mas da autoridade de legislador. E seria temerário considerar o Juiz a lei revogada pela sua inaplicação.

O conceito é de BAUDRY-LACANTINERIE et FOURCADE, que elucidam: "Quanto alla non applicazione della legge per promalgata che sia, essa può spiegarsi con molte ragioni del tutti strane all'idea della abrogazione ed anzi esclusive di questa, che sarebbe temerário considerare una legge come abrogata fatto soluche non esse osservata". (Delle Persone, ed. Valardi, $\mathrm{I}$, pág. $\left.103, \mathrm{n} .^{\circ} 123\right)$.

E tal é a irreprimivel fôrça dêsse princípio que êle aparece através do pedido mesmo, formulado que foi por eminente jurista: - em rigor técnico lê-se na petição, uma lei só se revoga por outra. E é nêsse "rigor técnico" que, traduz, antes que tudo, o princípio vero e legitimo a melhor censura de direito, que, a meu ver, se fortalece o Juiz, que deve ser tão cioso das prerrogativas do Poder que representa como cuidadoso c circunspecto em não romper as lindes em que êste Poder se situa.

Mas, se não aceito êsse argumento, acolho o terceiro.

Aliás, nêste ponto de vista firmemente coerente com o caso anteriormente julgado. No caso a que se referem os impetrantes e de que foi o relator o eminente Sr. Ministro LAUDO DE CAMARGO, a situação dos impetrantes ainda era mais favorável; tratava-se de alguém que foi chamado a Serviço Militar e que podia comparecer, mediante chamado da autoridade; a situação de constrangimento em que se achou, pelo Serviço Militar é muito menos colorida, muito menos forte do que aquela de réus que se encontram no estrangeiro por ato do Govêrno. De modo que se não há identidade entre um caso e outro, e para favorecer a hipótese presente, em que é mais destacada, mais sublinhada a criação em que se situam os pacientes.

Pela lei, a citação pessoal se faz aos presos, a edital se fazia ao sôlto ou foragido, pelo que não compreende a lei outra citação. Aplicado o art. 4, 
à acusação, que se lhes intentou. Banidos de sua terra, a que prestaram os mais assinalados serviços, ARmando de Salles Oliveirar como governador do Estado de São Paulo; Octavio Mangabeira como professor catedrático da Escola de Engenharia da Bahia, antigo ministro de Estado das Relações Exteriores da República e deputado federal pelo Estado da Bahia; e Paulo Nogueira Filho, como jornalista, diretor, que foi, do Diário Nacional, de São Paulo, e representante dêste Estado no Parlamento Nacional, como deputado - em nenhum momento deixaram de ser, como sempre foram, homens de dignidade e de honra, imbuídos do mais profundo sentimento patriótico. Banidos de sua terra, sofreram, sem processo, sumàriamente, irrefragável arbitrariedade. Licito não era ao presidente da República, mesmo em face da carta fascista, que êle ditou ao país, afastá-los dêste, comó o fez. As medidas, que ela lhe consentia, durante o estado de emergência, estavam limitadas à deten-

parágrafo único do Decreto-lei $n .^{\circ} 474$, de 8 de junho de 1938, interpretado civili modo, o que se vê o que a citação por éditos cabe quando o réu está "foragido" ou "sôlto". Cumpre ao Juiz verificar se os impetrantes se achavam na situação de pessoas "sôltas" ou "foragidas".

"Solto" não é apenas - e eu já o disse no anterior habeas-corpus - o que não se acha encarcerado, privado de liberdade de locomoção, de defesa; quem se encontra em destêrro, quem se encontra impossibilitado de acudir à citação é pessoa "não solta" para os efeitos da lei. E o legislador, ainda, e especial, não foi cuidadoso em garantir a defesa que, como observou o Sr. Ministro GOULART DE OLIVEIRA, em argumento de muito realce, na própria hipótese de estar o réu fora do distrito da culpa, aplicava-se a lei, quando aplicável, isto é: ao ausente se garantia o mínimo de citação, que é por edital. Esse mínimo seria claramente inútil, no caso a pessoa estar no estrangeiro. Seria uma citação ficta; o legislador pode fingir, mas a ficção tem limites na própria arte, na poesia, como observava HORÁCIO.

$\mathrm{Na}$ hipótese atual, era impossivel aos réus, estando um na Argentina, outro nos Estados Unidos, acudir a um édito, com 48 horas. Se o fim da citação é o chamamento proveitoso a Juízo, se êsse fím, no caso, estava impossibilitado, por obstáculo materialmente invencivel, aquela ficção de citação não podia preponderar.

Fala-se no art. 17 da Lei de Extradição, mas essa lei não cuida do problema da citação, versa o problema da ultra-territorialidade dá lei penal nos crimes cometidos no estrangeiro. De modo que a desadequação à espécie é conspícua e visível.

Coerente com meu voto anterior e pelo fundamento exposto, concedo. a ordem.

\section{VOTO}

o Sr. Ministro Castro Nunes - Sr. presidente, concedo a ordem pelo primeiro fundamento, nulidade do processo por falta de citação pessoal, e sòmente por êsse fundamento, porque estou de acôrdo com o Sr. Ministro Relator e com os votos manifestados no sentido de que não é possivel aceitar o argumento dos impetrantes de que a lei não executada fica revogada. 
ção em edifício ou local não destinado a réus de crime comum e ao destêrro para outros pontos do território nacional, senão ainda a residência forçada em determinadas localidades do mesmo território, com privação da liberđade de ir e vir. Tal dispunha o seu art. 168, nêste ponto não alterado pela lei constitucional n. 3, de 10 de março de 1942. Não obstante, foram deportados para o estrangeiro, mercê de violência inominável. Teriam, nêste trânse, formulado, contra ela, o seu mais veemente protesto, já que condenados, sem fórma, nem figura de juízo, a pena, a cujos efeitos ainda se acham submetidos e perdura por mais de seis anos.

Nesse protesto, que cada um formulara isoladamente, exercitando o direito sagrado de defêsa, mais não havia, em verdade, do que o profligamento do ato de ilegalidade e de extrema violência, que sôbre êles se desferira; e, ao mesmo passo, o exercício do direito, que lhes não poderia ser recusado, de manifestação de seu pensa-

Realmente, seria subversivo de tôda a ordem jurídica, se se admitisse tal argumento. A lei não se revoga ou derroga senão por outra lei. A tolerância da autoridade ou relaxamento na execucão de uma lei não basta para fazê-la desaparecer.

Em matéria de contravenções existem precedentes conhecidos que poderiam ilustrar essa tese. As administrações policiais que se sucedem ora intensificam, ora relaxam a repressão de certas contravenções. E jamais se pretendeu pudessem ser sôltos por habeas-corpus os réus sentenciados anteriormente, ao tempo em que os agentes do poder público estavam dando execução à lei. Não invoco êsses precedentes senão para mostrar ao vivo qne o afrouxamento ou a intermitência na aplicação da lei não basta para fazer desaparecer a infração. A situação juridicamenté, é idêntica, embora aqui se trate de crimes políticos, delitos de opinião, que se situam em grau superior, e não nodoam o agente.

Mas o primeiro fundamento, a nulidade da citação, se impõe à evidência. Realmente, não se trata, no caso, nem de rẻu sôlto, nem de réu foragido. De réu foragido não seria possivel cogitar na hipótese, porquanto o réu foragido é aquêle que procura escapar ou consegue escapar, sair do distrito da culpa, procurando esquivar-se, evadir-se ao processo, sem ciência ou iludindo a vigilância das autoridades. De réu sôlto igualmente não se trata, porquanto réu sôlto só é aquele que se pode locomover livremente no distrito da culpa, que pode ir e vir para onde entender. No caso, tratava-se de réus que foram convidados a sair do pais. Estavam soltos, é certo, mas em pais estrangeiro. Não é essa a hipótese de réu sôlto em face da lei.

O réu comprometido num crime político é convidado pela autoridade a retirar-se do pais a fim de não ser prêso.

Temos frequentemente os exemplos ocorridos na República Argentina, onde, aliás, a Constituição declara que, na vigência do estado de sítio, pode o govêrno prender ou desterrar para outros pontos do território nacional, salvo se o cidadão preferir sair do país. De modo que já è muito freqüente a adoção dessa prática e quando o próprio govêrno não convida o cidadão a retirar-se do país, é êle mesmo que pede seu passaporte, para procurar asilo em país amigo. 
mento sôbre as suas conviç̧ões democráticas, que o seu infortúnio não esmorecera, antes sublimara. Crime nisso não havia, nem podia haver, mas tão sòmente crítica, sob o ponto de vista doutrinário, do panorâma político brasileiro, em termos vivazes, por certo, mas à altura do insulto.

12. Tribunal político, na essência e na fórma, bem assim na finalidade, cujos juízes podem julgar por sua intima e secreta convicção, mais do que pelas circunstâncias do fato, preceitos da lei e princípios de direito - o Tribunal de Segurança Nacional divisou, no caso, a prática do crime politico. E condenou os três exilados políticos brasileiros, agravando, dessarte e sobremodo, a pena de destêrro, em cujo cumprimento estavam e ainda estão, porque de tempo indeterminado. Nisso, evidentemente, êle se excedeu. Tinha êle razões, que a razão desconhece. Os regimes totalitários fascistas, como o que se impôs ao Brasil por efeito do golpe de Estado de 1937,

De modo que, aqui como lá, não se trata pròpriamente de uma imposição, mas de uma injunção, de uma solução optativa. Dá-se ao comprometido na crise política, ao cidadão indiciado ou suspeito à autoridade, a opção entre a prisão e a saída do país.

Esta é que é a natureza da medida de cunho nitidamente político, não é pena, não é expulsão, e já então seria inconstitucional, é uma opção que se lhe dá para preferir à prisão em seu país à liberdade em outro país. Sem dúvida, é sempre preferível esta última solução que o govêrno não concede a todos, solução mais branda pelo menos para o cidadão que tenha posses que the permitam viver no estrangeiro, melhor do que sofrer as agruras da prisão política.

Ora, no caso o que se terá dado foi isso: a autoridade pública convidou os pacientes a se retirarem do país. Mas se eles não saíssem do pais seriam prêsos. De modo que réus no processo que ocorreu dois anos depois, eram réus virtualmente prêsos, não eram réus sôltos. Pacientes estavam fora do país porque o govêrno lhes permitiu a saída; mas, se voltassem, para se defenderem, serias prêsos. Estavam, pois, na situação de réus prêsos e teriam de ser citados pessoalmente, por mandado ou mediante rogatória para o país em que estavam. E o Tribunal sabia onde estavam êles, porque das sobrecartas constava a procedência de onde vinham os manifestos e panfletos. Aliás, o govêrno poderia por meio de suas representações diplomáticas localizar os réus.

Ả vista disso, só posso acompanhar o voto brilhante e exaustivo do Senhor Ministro Relator, dando o habeas-corpus, de acôrdo com essas premissas, para que os pacientes possam voltar ao país livre da condenação do Tribunal de Segurança Nacional.

Concedo a ordem.

\section{VOTO}

o Sr. Ministro José Linhares - Sr. presidente, voto de acôrdo com todos os fundamentos do Sr. Ministro Relator, reafirmando o voto anterior. Concedo a ordem, por nulidade da citação porque não se pode considerar citado por edital aquêle que se acha nas condições dos pacientes. 
inadmitem a livre manifestação do pensamento. Proscrevem o direito de critica. Só toleram, porque com êles condizentes, e são os elementos constituintes do clima político, em que podem viver e prosperar, o assentimento unânime, a bajulação sórdida e o incensamento perene, de todos os dias, horas e minutos, custe o que custar, pela comprenssão, pela adesão interesseira, pela corrupção ou pelo subôrno. Tudo quanto disso se afaste é crime.

E os três exilados brasileiros foram condenados..

13. Tudo, no mundo, passa. Passam os homens, mesmo os que se supõem eternos, na sua transitoriedade terrena, que não chega, em regra, a mais de um século. Passam os que se imaginam superhomens, criaturas eivadas de sôpro divino e, por isso mesmo, providenciais. Passaram Alexandre e Ciesar. Napoleão passou. Se não teve Mussolini ainda sua tumba, è porque os seus ossos devem ainda manter-se, para que o famoso duce dos fascistas sinta,

\section{VoTO}

o Sr. Ministro Lando de Camargo - Pelo que li no memorial recebido e pelo que ouvi do relatório feito, dois constituíram os motivos de pedir: a) nulidade do processo, por falta de citação e b) insubsistência da condenação, por não ser mais criminoso o fato articulado.

A nulidade teria advindo da circunstância de se acharem exilados os pacientes e sem conhecimento do processo, para a necessária defesa.

Foi realmente o que aconteceu.

Houve ausência não voluntária mas forçada. Determinou-a ato das autoridades brasileiras.

São, portanto, situações diversas e que se não confundem: a do que se retira e a do que é forçado a retirar-se.

So o primeiro pode locomover-se livremente, regressando, o segundo conserva cerceada a sua livre locomoção, com impossibilidade de regresso.

Sendo assim, os pacientes, como exilados e tolhidos na liberdade, teriam de ser citados pessoalmente, quando em lugar conhecido.

A sua situação se identifica com a do sorteado, que livremente não pode locomover-se, conforme o nosso julgamento, no caso de Sergipe e a que se reportou o pedido.

Vou mesmo além: maiores garantias deverá contar o que sofre restricões fora do país do que o que nêle se encontra nestas condições. E' que êste poderá comparecer pessoalmente, enquanto àquele êste comparecimento é negado.

Se, entretanto, conhecido não fôsse o lugar do exílio e impossívcl aguardar-se pelo regresso dos acusados, sob o fundamento de ser permitido o procedimento criminal, não obstante a ausência, dada a natureza do delito que se lhes atribuiu e o lugar da sua prática, tudo em contrário ao que decidiu o juiz de primeira instância, teria então lugar a citação por edital, mas em forma regular.

Já fiz apreciação ao texto legal, determinante da citação nos processos da alçada do Tribunal de Segurança Nacional.

Algo há ainda a dizer, não deixando de recordar as palavras de JOÃO MENDES, de ser preferivel não facilitar "o perigoso expediente da citação por edital". 
em sua própria consciência, a tragédia da sua lenta decomposição histórica. E Hitler, que sonhou ser senhor e possuidor do mundo, está a assistir, dentro dêle, ao desmoronamento do seu pequeno mundo germânico, destruido pelas armas das duas grandes democracias - a inglêsa e a americana.

Tinha, pois, que passar o fascismo brasileiro, compendiado na carta de 1937 e que os seus próprios autores, por suas próprias mãos, converteram, e quem o disse foi o talvez seu inspirador, Francisco Campos, em entrevista recentemente publicada nos jornais, em "documento de valor puramente histórico", que entrou "para o imenso material, que, tendo sido ou podendo ter sido juridico, deixou de ser ou não chegou a ser juridico, por não haver adquirido ou haver perdido a sua vigência.

Se não passou de todo, está visivelmente, no ocaso, que começou com o chamado ato adicional - a lei constitucional n. 9. Mrl-

Resa o art. $4 .^{\circ} \S 2 .^{\circ}$ do Decreto número 474, de 1934: “a citação será feita pessoalmente se o réu estiver prêso, enquanto sôlto ou foragido, por edital afixado à porta do Tribunal"

A só leitura do texto está a mostrar que, nem sempre, poderá a sua fria aplicação ajustar-se à regra geral e a merecer inteira observância: “a iustrução criminal será contraditória assegurada, antes e depois da formação. da culpa, as necessárias garantias da defesa".

E' certo que à lei ordinária cabe estabelecer a diretriz do procedimento. criminal.

Mas, não menos certo, que deverá fazê-lo de modo a atender, a não contrariar, ao enunciado pela lei maior.

Pelo texto, só o acusado prêso será citado pessoalmente. Ao que estiver sôlto, toca a citação por edital. E de que modo?

Pela simples afixação do chamado à porta do Tribunal, pouco importando que o interessado seja conhecido e tenha residência certa no lugar em que êle se acha instalado.

A presunção que daí pode decorrer será mais pela insciência do que pela ciência, uma vez desconhecido de quase todos o que ali ocorre diàriamente.

Razoável seria que, havendo imprensa, fôsse o chamado dado à publicidade, como de prática constante na processualística criminal comum e com prazo bastante.

Como conhecer o exilado o que veio a ser simplesmente afixado?

Dêste modo, na aplicação do texto, haverá sempre necessidade de atender às circunstâncias coerentes, de modo a não sacrificar-se o direito de defesa.

São ainda palavras do acórdão da condenação:

"a citação não traz ao réu sôlto qualquer prejuízo, de vêz que pode constituir advogado, e, se não o fizer, não poderá o juiz julgar sem nomear defensor".

Aí o êrro.

Uma coisa é nomear defensor, outra diferente constituir advogado.

Nomeia-se defensor ao que faltoso é.

A quem o não seja, assegurado fica o direito de constituir advogado que o defenda. 
dou-se, senivelmente, a ordem politica, abrindo-se, por fôrça das circunstâncias, tanto internas, quanto, e principalmente, externas, ou, melhor, internacionais, o debate em tôrno do sistema político e administrativo. Suspendeu-se a censura à imprensa.. Desde que isso aconteceu e se seguiu à visita de cortesia que o chanceler STETTINiUs, vindo de Moscou, fez ao presidente da República, muitíssimo mais do que teriam escrito os srs. Armando de Salles Oliveira, Octavio Mangabeira e Paulo Nogueira Filho, nas publicações, por via das quais foram condenados pelo Tribunal de Segurança Nacional, têm dito, e estão ainda dizendo, em termos muitíssimo mais vigorosos e candentes, homens públicos, instituições, academias, universidades, com o aplauso, a bem dizer unânime, de todas as correntes de opinião pública, sem que as autoridades tomem qualquer iniciativa processualística e sem que o Tribunal de Segurança Nacional thes desfeche o seu látego condenatório. Anexam-se a esta petição as moções ou manifestos, em tal sentido, da Faculdade Nacional de Direito, da Faculdade de Direito da Univensidade de São Paulo, da Faculdade de Direito de Recife, da Faculdade de Direito da Bahia, dos Institutos dos Advogados Brasileiros e de São Paulo, bem como da Ordem dos Advogados do Brasil, Secção de São Paulo, do Conselho da Universidade de São Paulo, e outros. Como, em tais condições, pensar na execução da sentença condenatória, pelo

Este direito, entretanto se prejudica, com a insciência do processo.

Tudo está, pois, a mostrar a nulidade pleiteada.

Assim, de acôrdo com o meu ponto de vista anteriormente manifestado, e sem necessídade de maiores considerações, concedo a ordem.

\section{VoTo}

o Sr. Ministro Bento de Faria - Sr. Presidente, no meu conceito, a única questão a considerax é a referente à citação, que se diz mal feita.

Mas, embora os pacientes tivessem sido citados pessoalmente, ainda assim, no caso, tal citação seria incapaz de produzir efeitos, porque se desejassem êles atender ao chamamento, estavam absolutamente impedidos de entrar no País, consoante a determinação do Poder Público, como decorrência do exilio compulsório.

E, assim, não poderiam comparecer perante o Tribunal que os condenou com evidente sacrifício do direito de defesa.

Por essa razão, vencido na preliminar de não conhecer do habeas-corpus em período de estado de guerra, concedo a ordem, de acôrdo com o voto do eminente Sr. Ministro Relator, cujas considerações, quanto ao mérito, subscrevo sem restrições.

\section{DECISÃO}

Como consta da ata, a decisão foi a seguinte:

Concederam a ordem, por unanimidade de votos.

Vencido na preliminar de não se conhecer do habeas-corpus, em vista do estado de guerra, o Sr. Ministro BENTO DE FARIA.

Impedido o Sr. Ministro BARROS BARRETO". 
mesmo crime, se crime se praticou, dos três exilados brasileiros, quando, agora, e evidentemente, crime tal não se considera? Não: é isso, acaso, repugnante ao sentimento de justiça? Permite a lei contrasenso de tamanha magnitude? Tolera a equidade, acaso, que pelo mesmíssimo fato, essencial e formal, uns se reputem criminosos e outros não?

14. Fornece o ambiente social as causas ocasionais do crime e, notadamente, do crime político, consistente nos atos tendentes a mutação da ordem política e social, existente em dado povo e país, em certo e determinado momento. Basta que se destinem a alterar a ordem política, embora inalterável permaneça a ordem social. Mudada a ordem política, os mesmos atos, que antes criminosos se reputavam, deixam de o ser, transformando-se, muitas vezes, os delinquentes em beneméritos, senão em heróis. Decorre disso, como tem sido acentuado pelos tratadistas, o carater de relatividade do crime político, sensivelmente mutável. Cumpre, para conceituá-lo, atender ao momento histórico, à época do comportamento punível e à transformação política ulterior, que o torne lícito ou penalmente indiferente. Dá-se o que denominou Mezaer, de "mitigação da relação jurídica", a propósito da legislação protetora das tendên.ias da democracia social, "abrrogadas as leis por decurso do tempo ou por outra causa, também a punibilidade tinha que cessar” (1).

O fenômeno é de observância mais frequente do que se imagina. Dá-se, até, inesperadamente, como aconteceu com a publicação do ato adicional de 1945. Dispensando êste a homologação plebiscitária a que se subordinou a eficácia da carta de 1937; admitida a possibilidade de sua outorga por simples manifestação unilateral da vontade do detentor do poder, mercê de ato de fôrça, ficou ela vazia de sentido e vigor. De outro lado, aquela lei, dita constitucional, acarretou situação diversa da anterior, introduzindo, em parte, condições políticas incompatíveis com as leis repressivas das manifestações da opinião, que explodiram em violência correspondente ao tempo em que estiveram comprimidas pelo regime férreo do mais estreito absolutismo, gêmeo do personalismo político dêste último e desastrado setênio. Abrrogaram-se aquelas leis implicitamente, por efeito da nova situação criada, tanto quanto por injunção vitoriosa do consenso popular. Não se acoime de infundado o asserto, porque, e foi Haus quem o observou, "muitas vezes também a legislador, sobretudo quando procede à reforma da legislação repressiva, realiza as mudanças de que se trata, modifi-

(1) Mezger, Diritto Penale, trad. italiana de Mandatari (Padua 1935), pg. 92. 
cando a definição de certas infrações, de molde a estender ou restringir a que lhe dava a lei precedente, fazendo assim entrar na disposição legal fatos que ela não compreendia ou eliminando dela atos que tombavam sob sua aplicação, qualquer que seja o modo escolbido pelo legislador para introduzir as mudanças que teve em vista". Mas não ficou nisso. Acresceu o velho criminalista que, "por outro lado, a lei que tira a um ato o carater delituoso, deve receber aplicação imediata, mesmo a fatos anteriores à sua publicação" (2). Eis ensinamento que se ajusta ao casoconcreto e não refoge da sistemática legal brasileira.

15. Ninguém (a dispositivo é do artigo 2 do código penal) póde ser punido por fato que lei posterior deixa de considerar cri-me, cessando, em virtude dela, a execução e os efeitos penais da sentença condenatória. Ora, condenados foram os três exilados. brasileiros por haverem externado suas convicções democráticas e sua repulsa aos regimes fascistas e totalitários. Não se póde mais contestar, em sã conciência, ter sido elaborada a carta de 1937, sob o influxo dos regimes políticos, que imperavam na Alemanha e na Itália, e quando o ditador brasileiro, convencido da vitória das duas potências em guerra com as democracias, resolveu entrelaçar a sua sorte e, com ela, a do Brasil, às daqueles países e seus governantes. Desde que, porém, empalideceram as estrêlas dêstes e as vitórias. nazistas se substituíram por derrotas espetaculares, que se sucederam em número e intensidade; desde que, premido pela opinião brasileira, o presidente da República, que recentemente se proclamou destituído de preconceitos de ordem política e partidária, se viu forçado a romper as relações diplomáticas e alfim a declarar guerra aos países do "eixo" - a transfiguração política do Brasil tinha que fazer-se, a despeito de retardada, no sentido democrático. Se, pois, crime político era a defesa das instituições democráticas, agora tal não acontece. Na própria exposição ministerial, que pro-piciou o ato adicional, se deparam conceitos e expressões, que antes a ninguém se permitiriam, sem que padecessem os rigores policiais e os anátemas do Tribunal de Segurança Nacional. A mudança da: ordem política, a despeito de tudo, é sensível. Urge, pois, que cessem a execução e os efeitos penais da sentença, por que ARMando de Salles Oliveira, Octavio Mangabeira e Paulo Nogueira Filho. foram condenados pela manifestação de seu credo democrático, que o primeiro, encerrando o Diagrâma de uma situação política, nestes: têrmos orou:

(2) Haus, Principes Généraux du Droit Penal Belge, 3.a ed. (Paris, 1879), vol. I, pg. 123 e 124. 
"Creio que o povo brasileiro possúe o instinto profundo do govêrno democrático e não se submete à sorte dos escravos voluntários. Creio que o problema da nossa unidade é o nosso problema fundamental e que seria uma geração execrável a que deixasse que se fracionasse em suas mãos a Pátria grande, herdada de seus páis. Creio que o sistema federativo, com as suas raizes mergulhadas nas origens de formação nacional, é o que melhor resguardará a nossa unidade. Creio que, na relatividade das instituições humanas, o principio majoritário é ainda o melhor método de decisão política; que êsse princípio só se póde fundar no voto popular, secreto e livre, nunca no plebiscito policial; e que a eficácia do método está em grande parte nas mãos dos govêrnos, pois tudo se resume num problema de educação. Creio que êsse voto deve ser coordenado através dos partidos políticos e que o princípio democrático é inseparável da idéia de responsabilidade e fiscalização e, portanto, da idéia de oposição. Creio que jamais a democracia brasileira será uma realidade se não se impedir que a organização partidária se fracione, não sòmente em partidos estaduais, mas ainda em absurdos partidos municipais; que a organização nacional dos partidos será a fonte de rejuvenescimento da vida democrática brasileira; e que só através dos partidos nacionais se corrigirão as desigualdades na importância política dos Estados e, por conseguinte, se robustecerá o ideal federativo. Creio no instinto das autonomias locais, que se revelou em épocas afastadas da existência do Brasil e que se fortaleceu sempre em tôdas as lutas da nacionalidade. Creio na necessidade de um poder político forte, sobretudo na União, mas desde que seja exercido por governantes temporários, sob as vistas da representação popular. Creio, porém, ao mesmo tempo, na necessidade de se manter a descentralização administrativa, para acelerar a circulação do sangue em todo o organismo da Nação e evitar que a hipertrofia do centro géle as suas extremidades distantes. Creio que a coesão nacional será alimentada com muito mais vigor pela cultura das peculiaridades de costume, das caracteristicas de temperamento e das tradições de cada região, do que pela sistemática, artificial e precária tentativa de uniformização de todos os brasileiros.

Creio que só na liberlade o espírito do homem pode conservar a. sua fôrça criadora, e que a personalidade humana é inviolável. Creio na cultura humanistica como o melhor instrumento de exercício da liberdade e de fortalecimento da coesão social. Creio que há uma crise aguda do individualismo e que a palavra liberalismo, no seu sentido integral, talvez não sobreviva; mas que as criticas mais profundas que se fazem a essa crise são as dos grandes espíritos, que ainda acreditam na liberdade; e que, em todo o caso, os 
remédios prescritos pelos contemptores da liberdade só produziram, por ora, guerras de conquistas. Creio na solidariedade e na cooperação sociais como princípios inspiradores de qualquer organização dos nossos dias. Creio que, dentro do atual panorama do mundo, o problema brasileiro está pôsto em têrmos de sua independência. Acima de tudo, creio no Brasil. Esse Brasil é democrático".

Transpiram palavras dêsse naipe nobreza de propósitos, dignidade humana, sadio e corajoso patriotismo. Merecem os que as emitiram aplausos e bênçãos. Não a condenação. Muito menos, o presídio. Poucos já não são os anos amargos do exílio.

16. Perdendo o fato seu característico criminal, mercê de lei posterior, esvái-se a sentença por que antes se condenara, cessandose sua execução, se já iniciada, ou tornando-se inâne, se não ainda. Desaparecido o crime, desaparece a pena. Diluem-se em nada os efeitos penais da sentença condenatória. Mais ainda. Favorecendo ao agente lei posterior, de qualquer outro modo, aplica-se ao fato não definitivamente julgado e, na parte em que comine pena menos rigorosa, ainda ao fato julgado por sentença condenatória irrecorrivel. Com êsse, não com outro espírito, todo equitativo, e, por isso mesmo, justo, deve-se examinar o crime político, principalmente quando cometido, como no caso teria sido, mais pela manifestação do pensamento, do, que por atos. Alteradas as cincunstâncias que o caracterizariam, ou caracterizaram, não há puni-lo.

17. Acolhida não mereceria, por certo, argumento, que no art. 3.0 do código penal se fundasse. A lei excepcional, nêle se prescreveu, ou temporária, embora decorrido o período de sua duração, ou cessadas as circunstâncias, que a determinaram, aplica-se ao fato praticado durante sua vigência. O fato criminoso, dessarte, cometido em momento que tal fôsse a ordem política do país, mudata esta, punivel ainda se torna, a despeito de cessadas as circunstâncias, por via das quais se erigiu o crime político em figura de direito penal. 0 argumento, ao pé da letra, induziria a absurdidades simplesmente espantosas e inconciliáveis com o senso juridico.

Pouco importa que se defina o crime político no código e entrosado no sistema dêste, ou que se qualifique e discipline em lei separada ou especial. Esta, no caso, não é excepcional. De duração periódica, muito menos. E' crime como os demais da mesma natureza. E tem-se, pôsto isso, o motivo impediente do argumento, esboçado mais com ânimo de discutir, prevenindo, que de dar por sua legitimidade.

Como lei especial, abrrogável é ela pela geral posterior, sempre que seu conteúdo contraste com a norma por esta editada. Sustentou-a tratadista italiano, referindo-se até aos atos dos govêrnos pro- 
visórios, entre os quais se incluem, certamente, os mais duradouros, mas de fato, sem organização jurídica definida, como a ditadura brasileira. As prescrições dos govêrnos provisórios, doutrinou, abrrogam-se quando contrárias a principio de órdem pública contido em leis gerais para todo o reino, assim que entre em vigor a norma nova. Vale isso, são de RAGGI os conceitos, considerar a lei penal como inaplicável (interpretatio abrogans), onde não seja possível remover sua contradição com outra lei ou algum princípio fundamental de direito (3).

Ora, o principio fundamental do direito constitucional brasileiro é, no capitulo dos direitos e garantias individuais, o da livre manifestação do pensamento. Todos, em face do art. 179 , n. 4, da Constituição do Império, podiam comunicar os seus pensamentos com palavras, escritos, e publicá-los pela imprensa, sem dependência de censura, contanto que respondessem pelos abusos que cometessem no exercício dêste direito, nos casos e pela forma, que a leí determinasse. Em qualquer assunto, pelo dito no $\S 12$ do art. 72, do capítulo da declaração de direitos, da Constituição da República, de 1890, era livre a manifestação do pensamento, nos mesmos têrmos do dispositivo constitucional anterior. Não divergiú, nêste particular a Constituição de 1934.

Dês que, pois, ordenânças de govêrno ditatorial coibiram a manifestação do pensamento, notadamente em matéria de direito constitucional, quando pretendeu impôr ao país, pela fôrça, a doutrina totalitária germânica ou italiâna, puseram-se em contradição nítida com o principio de ordem pública, secularmente dominante no Brasil e em todos os mais países policiados do mundo. Mudaram-se, porém, em dado momento, o que agora vivemos, as circunstâncias determinantes dequele sistema. Abrrogaram-se aquelas nórmas, por fôrça de novas circunstâncias, que ensejaram a livre manifestação do pensamento, independentemente de censura prévia, mesmo sôbre o regime político imposto em 1937, e que tem sido descarnado sem maiores recatos, como se se tratasse de cadáver de indigente, em mesa de necrotério público, submetido a autópsia.

18. Leis outorgadas por ditadores têm valimento e eficácia apenas enquanto perdure o estado de coação permanente do espírito público. Revogam-se por sua repulsa unânime, tanto que se quebrem os grilhões a que o povo ficara submetido. Confina com o asserto o ensinamento de LASKI de independer a valia da lei não tanto da fonte, de que emane, quanto, e muito mais, de sua aceitação espontânea e generalizada. Expressão apenas de poder, carece o

(3) RAgGi, Della Legge Penale e della sua Applicazione (Milão, 1927), pg. 32 e 43 . 
direito positivo de assento em principios que lhe sobrepairem (4). Coincidente com êsse pensamento é o de Cathrein. "Sendo", escreveu êste, "sendo a lei nórma obrigatória, verdadeiramente lei não poderá ser preceito algum contrário à razão. A obediência dos súditos precisa ser racional e não o seria se se lhes exigisse subthissão a lei contrária à razão; seria essa obediência, de outro modo, renúncia do homem à sua verdadeira dignidade, à elevada qualidade que possúe como ser racional e livre. A lei de Nabucodonosor, que prescrevia a admiração de sua estátua, e a de NERo, que exigia honras divinas para o seu cavalo, eram notòriamente imorais e não era lícito obedecê-las, a não se querer obrar imoral e irracionalmente" (5).

Fóra de dúvida, as leis fascistas, que no Brasil imperaram, constrangendo as conciências, impondo o silêncio forçado do pensamento, exigindo a admiração incondicional do peão gaúcho, de caudilhismo estilizado pela sua propaganda, insistente e carissima aos cofres públicos, cederam diante da rebeldia nacional, que é evidente e vitoriosa. Vai para dois mêses que as comportas se abriram, impotentes à fôrça das águas. Não existe canto, nem recanto doutrinário ou administrativo, que esteja interdicto à crítica da imprensa ou da tribuna radiofônica, quando não dos comícios populares, frequentes e desabusados.

19. Em rigor técnico, a lei sòmente por outra lei se revoga, ou derroga. Quando, porém, se legisla torrencialmente, como tem acontecido nêstes sete anos de ditadura fascista, a tal ponto que existem inúmeras leis que não chegaram a executar-se, tendo existência virtual ou potencial simplesmente, muitas caídas em inteiro desconhecimento por ação do tempo; anomalia não é acentuar a fôrça dêste como destruidora das leis ou decretos-leis postos no olvido no mesmo dia em que publicados. $\mathrm{O}$ fenômeno é irrecusável. Inúmeros decretos-leis desvitalizaram-se e destituíram-se de autoridade, por abandono deste, autêntico suicídio legislativo. Bateu Brnding na tecla, de singular ressonância, no tocante à inércia do próprio legislador, maior, certamente, quando também êle é o executor. Aludindo à norma penal, advertiu que "quando a inação do legislador repousa na impotência, deixando de conservar a lei, pode-se supôr que não tenha êle querido mais conservar as limitações ou manter

(4) H. LAskr, o Direito no Estado, trad. de Azevedo Gomes (Lisboa), pg. 20 e 50.

(5) Cathrein, Filosofia del Derecho, trad. espanhola de JQRDON E BARJA, 3.a ed. (Madrid, 1941), pg. 54. 
as proibições nela estabelecidas, mas, antes de tudo, satisfazer às exigências do desenvolvimento progresssivo do direito" (6).

Fato é, inconcusso e sugestivo, que não é mais crime, no Brasil, fazer a propaganda democrática, que é contrária à ordem pública fascista, nos têrmos da carta de 1937. Desabou sôbre ela o temporal dos anátemas de tôdas as conciências livres. A marcha é, inevitàvelmente, para a organização política do pais nos moldes democráticos, ao sabôr da tradição, mais que secular, de povo livre e senhor de seus destinos.

20. Revogada a lei, sob cujo império tiveram os pacientes, os três grandes brasileiros exilados, o prêmio de sua condenação; revogada, senão explícita, implicitamente, em consequência da mudança de órdem politica, que ela se destinava a preservar, quando não pela dessuetude e reprovação geral - tem, necessàriamente, que haver-se por cessada a execução da sentença condenatória e todos os seus efeitos penais.

Nem existe por que se mantenha a repressão, no caso. Inspira ao magistério penal e regula-se êle pelo princípio da pena, ditada pela justiça, tanto quanto necessária. "A autoridade", como advertiu Crivellari, "a autoridade social não tem direito de punir, senão nos limites da pura necessidade; desde que, portanto, o fato não seja mais declarado delituoso, evidentemente, pelo principio da necessidade de pena, não póde êle mais punir" (7).

E' o que se espera que seja proclamado, no caso, vertente, pelo mais alto Tribunal do Brasil.

\section{CAPITULO IV}

\section{Conclusão.}

21. Depende a autoridade da lei de sua aptidão para receber o assentimento mais ou menos geral de todos os cidadãos. Lei que se não imponha por motivos racionais aos a quem deva aplicar-se, acaba sempre em impasse e dá em resultado o desdém pela idéia mesma da lei. Disse-o Harold LASKI, para quem o problema da liberdade se tornou premente, em virtude de consistir sua salvaguarda a condição sem a qual não há vida civilizada; onde o fascismo aferrolha a liberdade, a flama do espirito humano se extingue. Disse-o o notável professor da Universidade de Londres, ajuntando ser princípio elementar de psicologia criminal a impossibilidade de

(6) Binding, Compendio di Diritto Penale, trad. italiana de Borettini (Roma, 1937), pg. 127.

(7) Crivellari, Il Codice Penale per il Regno d'Italia (Turim. 1890), vol. I, pg. 114. 
erigir em crime atos que $a$ priori a maioria das pessoas como tal não considera (8).

Se, pois, a maioria da população brasileira não considera crime, antes condição imprescindível da subsistência da Nação, no conúbio universal, a par da liberdade de pensamento, a fórma democrática de seu govêrno; mas se, de outro lado, govêrno de fato, fascista desde a medula até sua fórma exterior, cerceiou a liberdade de pensamento e condenou os que, no exercício dêsse direito: elementar, pregaram, antevendo os acontecimentos, a necessidade de restaurarse o regime democrático no Brasil - a sentença, que os condenau, sucumbe ao pêso de gravíssima injustiça, além de incompatível com a ordem política do momento histórico que passa. Nâo é ela, em tais condições, suscetivel mais de ser executada, sem que, para tanto, se subvertam os princípios de direito, sob cuja égide tem vivido, gloriosamente, o povo brasileiro.

Ademais, e antes de tudo, ela se proferiu em processo radicalmente nulo.

23. Cabe habeas-corpus sempre que alguém sofra ou se ache na iminência de sofrer iviolência ou coação ilegal na sua liberdade de ir e vir, salvo nos casos de punição disciplinar. Considera, de resto, o art. 648, ns. VI e VII, do código de processo penal, coação ilegal a manifesta nulidade do processo, bem assim a instauração dêste, extinta a punibilidade. Do mesmo modo, é de concluir, o julgamento dêle, ou ainda, a execução da sentença nêle proferida. Que é manifestamente nulo o processo em que se lançou a sentença condenatória dos drs. Armando de Salles Oliveira, Octavio Mangabeira e Paulo Nogueira Filmo, à saciedade se demonstrou, sobretudo em face do acórdão de 3 de dezembro de 1944, consignado nos autos do habeas-corpus n. 28.872, do Estado de Sergipe. Que a sentença é injusta e inexequível, diante da mudança das condições que alteraram a ordem jurídica, que poderia justificá-la, se nula não fôsse, é de incomparável évidência. Eis a coação ilegal. Violência inaudita, por último, constitúe o exílio forçado dos três brasileiros, sôbre os quais a ditadura desfechou o raio da sua perseguição.

Concedendo-lhes a ordem de habeas-corpus, que em favor dêles se impetra, para que cessem a violência e coação ilegais, de que são vítimas, de molde a poderem, livres de culpa e pena, retornar a sua Pátria, o Egrégio Supremo, Tribunal Federal, substituindo o arbitrio pela lei, cumprirá, mais uma vez, sua alta missão, de incorruptivel nobreza, como poder moderador das rudezas governamentais e assegurador dos direitos do homem.

(8) Harold LASki, La Liberté, trad. francesa de ARnaud DaNDIEU \& Robert Kiéfé (Paris, 1938), pgs. 5 e 121. 